University of Louisville

ThinkIR: The University of Louisville's Institutional Repository

Electronic Theses and Dissertations

1939

\title{
Basic philosophic themes in the drama of Eugene O'Neill.
}

Nancy Mae Warren

University of Louisville

Follow this and additional works at: https://ir.library.louisville.edu/etd

Part of the Literature in English, North America Commons

\section{Recommended Citation}

Warren, Nancy Mae, "Basic philosophic themes in the drama of Eugene O'Neill." (1939). Electronic Theses and Dissertations. Paper 1938.

https://doi.org/10.18297/etd/1938

This Master's Thesis is brought to you for free and open access by ThinkIR: The University of Louisville's Institutional Repository. It has been accepted for inclusion in Electronic Theses and Dissertations by an authorized administrator of ThinkIR: The University of Louisville's Institutional Repository. This title appears here courtesy of the author, who has retained all other copyrights. For more information, please contact thinkir@louisville.edu. 


\section{UIIVERSITY OP IOUISVIIIE}

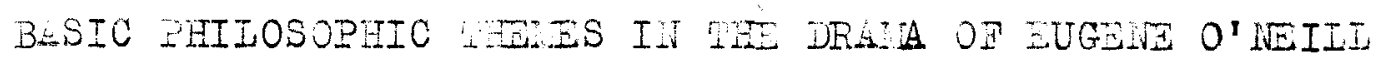

A Dissertation

Subritted to tine igculty

Of the Grajuate School of the University of Iouisville

In Partial rulfillment of the

Reguirements for the Degree

Of lister of Arts

Department of English

$\mathrm{By}$

WAICY MAE WARREN 
Chapter one

The Problem of the Possessive spirit

Chapter wo

The Problem of the Creative soirit

$\cdot 4$

Chapter iniee

The Problem of tan's Salvation 66

Chapter Four

Conclusions

82

- Bibliogreping

91 
Introduction 
Eugene O'Neill, as the outstenaing contemporary American äram tist, has been in the limelight of the critical world, both professional and lay, because of the content ana technicue of his plays. The professional critic has had much to say about agene O'Neill and aramatic technique. With thet we are not concerned. The professional critic, on the other hand, has little to contribute to the understanding of the philosophic themes in Eugene O'Neill's drama.

One of the critical gentry, for example, tells us that $O^{\prime N e i l l ' s ~ " f u n d a m e n t a l ~ f e e l i n g ~ f o r ~ t h e ~ s t a g e . . . ~}$ is not that of the artist, but of the melodramatist: the seeker after sensational efiect." ${ }^{1}$ Several critics suggest that his basic problem is the conflict between good and evil, but the statement of Halfora Luccock is

1. Zabel, lorton Dauwen, editor, Literary Opinion in America, "Eugene O'iveill" by Francis Ferguson, p. 216.

2. Richara Dana Skinner states that the underlying theme of O'Neill's work "is the conflict of good and evil, a picture in objective form of the stretching and tearing of a soul between a will towara the good and an appetite for the revolt of sin. In its aeper sense, it is a quest for a resolution of this conflict anā for ultinate peace." Skinner, Eugene O'Neill: A Poet's Quest, pp. 3-4. In the same vein, Trilling states that Orili's "quasi-religious function is to affirm that life exists and is somehow good (and that the problem of evil is solved by the courageous affirmation of life in the face of individual defeat." Trilling, Iionel, "Eugene O'Neill," The Hew Republic, Sept. 22, 1926. 
most representative of the whole of $0^{\prime}$ Neill criticism. He says: "[O'Neil]'s] work has the aspect of a dark forest, quite too intricate ana obscure to be mapped by any neat set of charts designed to 'explain' his meaning."

It is the aim of this paper to point out the major philosophic themes in O'Neill's plays and to show how they are evolved. For this purpose re have turned to the field of analytic psychology of aid in interpretation, finding in the psychoanalytic concept of libidinal cathexis a basic idea upon which to hinge the analysis of O'Neill's plays.

In order to establish $0^{\prime} N e i l l ' s$ philosophy we raised three questions pertinent to his use of libidinal cathexis as the points of analysis of the plays. These questions, listed in an ascending order of imnortance, are as follows:

1) Are sex problems used merely as action-situations for meloärama?

2) Are they used as a means of depicting character and forwarding dramatic action?

3) Are they used as a means of expressing philosophic ideas?

1. Iuccock, Halford $\bar{E}$., Cortemporary American Iiterature and Religion, p. 154

2. By libiainal cathexis we mean the accumulation of psychic energy in the particular channel of the libido. William Eealy, Augusta Bronner, Anna Mae Bower, The Structure and Meaning of Psychoanalysis, p. 8 . 
The third question, if answerea affirmatively, immediately brings in two more questions: in what way is this philosophical expression accomplished? what is its sum and substance?

It is obvious that the first question, Are sex problems used only as melodramatic situations? will be answered as conclusively as may be once the answer to the thira question is arrived at.

Similarly the answer to the second question, Are sex problems useà as a means of depicting character and of forwarding dramatic action? is also implicit in the answer to the thira question; particularly so, si nee character and dramatic action are, for the dramatist, necessarily means for the expression of iaeas, philosophic or otherwise. bcordingly, this paper may be centered about the third question and by answering it will also answer the other questions that have been postulated.

This can be accomplished through an analysis of O'Neill's use of the following aspects of the problem of libidinal cathexis: the problem of the possessive spirit with its correlative problem of sex antagonism; the problem of the creative spirit; the problem of how man may achieve psychic salvation, that is, satisfactory adjustment to his environment. 
Since our concentration is up on the se problems, especially insofar as they lend themselves (if at all) to the expression of $0^{\prime}$ Neill's philosophy (that is, his answer to the questions, 'How can life be justified in terms of existing externalities?' and 'How can life be made livable?'), the following early one-act plays need not be dealt with at all since they embody an experimental striving towara a mature grasp of technique, a striving haräly at all concerned with the expression of ideas:

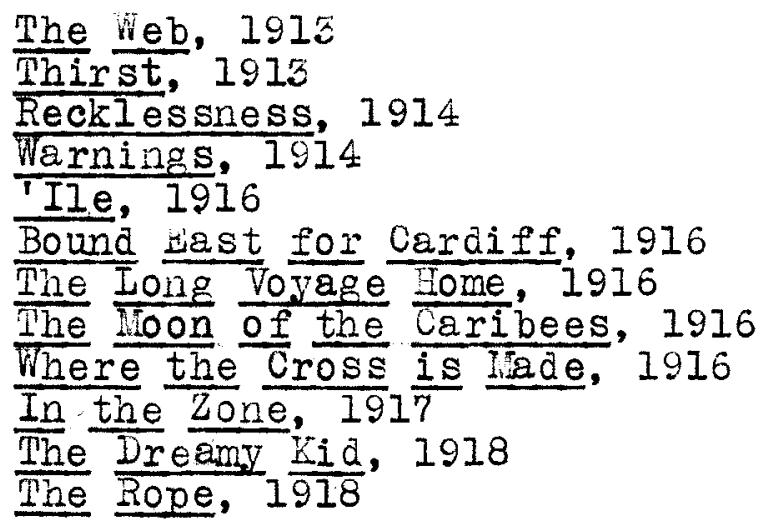

Emperor Jones, 1920, is al so consià er ed outside our fielả of study since it is a theatrical tour de force, with its focus on the occult ratier than the libidinal.

A chapter shell be devoted to each of these problers. These three chapters will each have a like development. H'irst, the particular problem will be defined so the reader will understand more clearly its relation to psychoanalysis and its possibilities or imposeibilities for dramatic treatment. Secona the plays containing some aspect of it will be analyzed. A system of cross-reference 
is used which will inai cate those plays that are referred to in more than one context; this should be helpful to the reader who is interested in following out this particular Iine of investigation more thoroughly in any one play. Third, what are O'Neill's conclusions; '́oes he or does he not offer a suggestion as to how the individual may make a satisfactory aojjustment which will overcome the aifficulties put upon him by the particular problem, or, in other words, how may Iife be justified? how may it be made Iivable?

The fourth chapter will briefly recapitulate the findings of the preceding chapters and thus bring the results of our research more directly to bear upon the central problem of the paper.

A clear understanding of this paper presupposes a general knowl eage of the tenets of psychoanalysis. Fxplanation of highly specialized terws will be given as they appear in the body of the paper. In this connection, the references to the handbook of psychoanalysis, The Structure and Heaning of Psychoanalysis by Healy, Bronner, and Bower are justified in that this book is a compendium of all the schools of psychoanalytic investigation in a highly conaensed form, the use of which eliminates much unnecessary wordage in references. 


\section{Chapter One}

The Problem of the Possessive Spirit 


\section{Chapter One}

The Problem of the Possessive Spirit

This problem has three aspects. The first is made up of the difficulties arising from the possessive spirit of the female and its converse, the desire of men to be possessed as by a mother. This includes among the situations and conflicts to which it is basic the antagonisms of the sexes, especially those having to do with the smothering and limiting possessiveness of the female contrasted to the more or less objective possessiveness of the male. The second is the psychic possession of persons by an exterior force--of which the sea in Anna Christie might be called a classic example. The third is the drive to material possession, more commonly known as greea or cupidity; which for our purposes may be considered to have its root in libidinal cathexis.

The use of these different aspects will be made clear as the plays in which they appear are analyzed.

The smothering possessiveness of the feminine spirit is first used in Before Breakfast (1916). The obvious situation in this play is the common one of a couple, entirely unsuited to each other, who married because of a child conceived out of wedlock. The very brief action is made up of the scolding, abusive harangue of Mrs. Rowlanả, delivered as a monologue as she prepares breakfast while the husband, unseen, shaves in the bathroom to the rear of the stage. The upshot of the tirade is the husband's suicide by throat-cutting with the razor. 
Whach of Iirs. Rowland's spitefulness and meanness can be attributed to the fact that she feels her husband has a Iife Which she cannot enter; thus her smothering possessiveness is frustrated. This is shown in her reference to Helen, the girl whose letter she had slipped from her husband's pocket and read while he was still asieep.

...I'm not the only one who's got you to thank for being unhappy. There's one other, at least, and she can't hope to marry you now. How about Helen? Yes, I read her letter.... I got a right to. I'm your wife... I know you'd be glad to have me dead and out of your way; then you'd be free to run after all these silly girls that think you're such a wonderful, misunderstood person---this Helen ana the others... Who is this Helen, anyway?... I'lI bet she told you your things were the best ever, and you believed her, like a fool. Is she young ana pretty? I was young and pretty, too, when you fooled me with your fine poetic talk; but life with you would soon wear anyone down... I'm sorry for this Helen, whoever she is. Haven't you got an feelings for other
poople?

Her love is not big enough to permit her to relinguish possession of him even when she knows that freedom will bring him happiness. Even his death causes grief only insofar as she feels that that which she possessed has slipped from her grasp.

Beyond the Horizon (1918) affords another example of the use of this smothering possessiveness of the female. The story of the play is that of two brothers, Robert and Andrew Nayo, and Robert's wife, Ruth. Robert is a àreamer,

1. Before Breakfast is a one-act play. Throughout the paper the quotations will be documented directly at their termination by act and scene, or by act only Where there are no scene divisions. 
a man of unstable will, a seeker after beauty and the mystery of far-off places. Andrew is of the soll, a man of action and quick decision. Ruth is a narrow-minded possessive young girl, jealous of anything which does not bow to her ego.

Robert is planning a three-year voyage with his uncle, while Anarew plans to work on the farm, exulting in nis love of the soil. The brothers, however, fina their plans suddenly changed when Ruth, on the eve of Robert's departure, tells him of her love, which he returns. Immediately she demands that he stay at home, give up his voyage to take care of her.

You won't go away on the trip, will you, Rob? You'Il tell them you can't go on account of me, won't you?... We'll be so happy here together where it's natural and we know things. Please tell me you won't go!

At first Robert is content to stay at home, believing that much of his desire for the unknown had been aue to his unexpressed love for Ruth.

Perhaps after all Andy was right -- righter than he inew -- when he saia I coulä fina all the things I was seeking for here, at home on the farm. I think love must be the secret -- the secret that called to me from the world's rim -- the secret beyona every horizon; and when I did not come, it came to me. Oh, Ruth, our love is sweeter than any distant dream. 
But these areans of Robert's are not so easily put asiỏe. It is the quality of the creamer in Robert which had fascinated Futh, but she is jealous of these dieams. They give him something for which he aoes not need to denend on her -- so thut she cannot completely possess him. Lndrew takes Robert's place on the vojage and stays in Brazil as a grain sneculator. The years on the farm are hard for both Ruth and Robert. Fe falls ill with tuberculosis, ana she hardy cares. By this time che hates him and his areamer's inability to produce. She tells him, finally, since she still is unable to dorinate him completely, that she has always 10 ved Andrew and that she hates him. Finally, after Andrew returns, Robert dies, still dreaming of something beyond the horizon.

For our purposes, the interesting ficet of the play is O'Neill's use of Ruth's possessiveness as the germ from which is derived the traqedy of the play -- the larger frustration of all three of the main characters.

1. In this reletion we have the germ of an often repeated theme of O'Neill's, the possessive spirit of the woman binding and rilling the thing it loves. Cf., Before Breakfast, Welded, Hourning Becomes Electra, and Strange Interluãe. 
The Straw (1918) is the story of two people infected with tuberculosis who meet at a sanitarium. Eileen Carmody falls in love with Stephen Wurray, a newspaper man, but he has only friend ship for her. As a result of their close companionship and Eileen's encouragement, Lurray begins to take an interest in creative writing; Eileen's health impro ves rapidy. His success at creative writing returns him to a state of mental ana physical sufficiency. On the night of his departure, Eileen reveals her love for him -but-he has nothing to give her in return.

Thereafter, Eileen's ajecline is swift. Hurray writes to her occasionally ana finally stops entirely. Several months later, he fears the return of the disease and comes back to the sanitarium. A nurse takes it upon herself to tell him about Eileen -- that she has given up hope and will die unless stephen can rekindle the desire for life by giving her something to live for. Moved by the nurse's story, but still not recognizing how much of his success has been aule to Jileen, he goes to her, asks her to marry him.

Possession is here revealed as a source of health and creativeness; this is symbolized by linuray's success at writing and Eileen's improved heal th under the good stimulus of their close companionship. The breaking of this partnership, this belonging together, brings about Eileen's decline, the retum of the disease to lurray. Here O'Neill 
is saying by implication that possession can sometimes be a good means to self-realization.

Gold (1920) is marked by the first appearance of the greed motif. In the opening act, the crew of a wrecked whaler, the Sarah Allen, find a chest of gold and jewels, as they suppose, and, crazed by the heat and thirst, murder the cook ana ship's boy for declaring the treasure to be but brazen junk. The rest of the play deals with the captain at home. He gradually becomes insane under his guilty secret, causing his wife's death, wrecking the life of his daughter and demoralizing his son. In Golà, O'Neill has isolated greed as an aspect of the spirit of possessiveness and has shown how a life centered here alone degenerates in its voià of human qualities --- love, humility anä sacrifice. Anna Christie (1920) deals with the reclaited love of a sailor for a prostitute. The problem uncer consideration is involved both in the possession by the sea of the three main characters who both love and fear it and in the parect's unwilingness to see his aaughter taken away from him by another man. The three since they belong to the sea are miserable and unhappy when out of its influence. Yet the two men, and Chris especially, are fearful of giving themselves wholly to that which claims them -- a note of reticence found in most of O'Heill's male characters, due perhaps to the underlying fear in the male that in giving himself fully 
to any outside force or ideal there is danger of destruction of the male ego. 'With Anna it is different; she not only knows she belongs, but she feels that she does. She is happy only in belonging completely -- a statement true of most of O'Neill's mature, feninine characters. The tragedy of Anna's life is that she cannot belong completely to Hat. 6 part of her pride and self-respect can never be regained, even though the love which liat has for her helps her nearer the goal of becoming socially accepted. Neither can she possess Mat fully because a part of him is of the sea. So it is that through the love of these two that O'Neill plays once again upon his recurrent theme of possession and belong ing.

Diff'rent (1920) is based upon the problem of feminine possessiveness so strong that it refuses to accept the world as it is. In explicit terms, its tragedy arises from a rigid conception of the single standara of sexual ethics so tenacious and inhuman in aspect that it destroys both the 3

woman and the man she loves. The woman, Emria, dismisses

1. Cf. Robert and Andrew in Beyond the Horizon, Dion and and Billy in The Great Goa Brown, Ioving in Days Without Find, Ned in strange Interlude, Tichael in We Polo in Marco Millions, and Stephen lurray in The straw.

2. Cf. Miriam in Lazarus Laughed, Bileen Carmody in the Straw, Elsa Ioving in Dazs Without Enä, ana Tukachin in Marco Millions.

3. About this play we have the statement: "Let the ideal of chastity repress the vital forces... and from (a) fille girl you will get a filthy harriadn. 'he nodern life crushes the affirme tive ana creative nature of man." Trilling, loc. cit. 
her affianced on the eve of their marriage because of a tale she has heard. Later, after thirty years of spinsterhood ano of faithfulness on the part of caleb, the ex-fiancé, she falls in love with Benny, his worthless young nephew. When Caleb finds that she plans to marry Lenny he kills himself. 'this action brings Benny's confession that he wanted Imma only for her money, and Imma, crushed by disgrace and humiliation, follows caleb in death.

Difi'rent is, then, a study of the distortion that comes to the feminine soul which is denied, sud aenies, its innate purpose and attempts to succor itself on an abstract ideal contrary to its own nature. Emma has built up an iàesl of caleb enỏowing him with inhuman virtues of extreme self-control and abstinence in face of great temptation; therefore, she rejects him when she learns of his one breach of the moral coae with a native South sea islander. Every one thinks the story a good joke on Caleb, noted for his continence, a quality the possession of which differentiates him considerably from most of his fellow seamen. Emma's mother begs her to forgive Caleb and to marry him. She says:

It'a be jest like goin' agen an act of rature for you not to marry hin. Ever since you was chilaren you have been livin' siàe by side, goin' round together, and neither you nor him ever did seen to care for"no one else... You' ought to remember all he's been to you and forget this one little wrong he's done. 
Emma cannot forgive him, not because she cannot forgive the mistake in itself in other men, but because it makes Caleb into a person no aifferent from the rest. When Caleb pleads with her to take him back, she says: ... I ain't got any hara feelings against you, Caleb... It ain't plain jealousy---what I feel. It ain't even that I think you've done a terrible wrong. I think I can understand -- and make allowances. I know most any man would do the same, ana guess all of 'ern I ever met has done it... I guess I've always had the idea that you was ... diff'rent... And you was diff'rent, too! And that was why I loved you. And now you've proved you ain't. Anà so how can I love you any more?... You've busted something way down insiàe me -- and I can't love you no more.

(I)

This statement gives the particular and peculiarly dangerous form that Emma's possessiveness has taken; she must have something better than the rest, an incarnation of an ideal. But $s$ he does not stop there. Immediately after her break with Caleb, she inveigles him into promising that he will never marry, but will wait even thirty years, if need be, for her to change her mind. Emma is akin to the Ruth of Beyond the Horizon, who also wanted to possess so much that she got nothing.

The deady frustration that resulted from this extreme of possessiveness is concretely illustrated in Enma's perverse attempt to gain the love of a man young enough to be her son and in Caleb's suicide brought about by her announcement of her marriage with this youth, his dissolute nephew. 
As a psychological stuay, Emma is typical of those women who frustrate their lives by regression to a chilaish failure to different reality from the ideal, or phantasy, world. It is well to note that throughout O'Neill's plays it is usually his women characters who fail to make the transition from the phantasy worlo of the chila and the adolescent to the worla as it is of the mature adult. They rely upon their emotional natures to carry them through Iife ana frequently fail to make satisfactory sublimation of their basic urges when these have been thwarted either through their own mental conflict or en vironmental circumstance. This olay is complete in its expression of the negation and frustration of the feminine essence and the distortion of the masculine by lack of realization of the creative spirit as symbolized in sexual union.

In The First Man (1921), the usual pattern of our problem is reversed in that it is the male who woula possess his mate even to the limit of asking for the death of the creation (that is, the chila) which would clain any part of her from him. Under a subterfuge of sorts, the anthropologist, Curt Jayson, has gotten his wife to vow never to have any more children as a means of memorializing the two of theirs who had died. This childlessness enabled the wife to accompany him on his long trips of exploration, enabled him to possess her wholly without that diffusion almost always contingent upon the bearing and rearing of 
children. His wife's announcement, just as he is preparing for a five-year journey, of the coming of another child shatters his worlo, out after her death in childbed he is able to make some re-adjustment in his feeling of tenderness for the child and in his defense of it against the charge of being another man's.

Welded (1923) is the story of a married couple held together by a deep attraction and a real admiration for each other, yet kept apart by a fear of losing inaiviaulity to the other. Ileanor Owen is an actress; lifichael Cape, her husbana, a playwright. So intense is their love for each other that each resents its absorption of their inaiviauality. At the height of one of their frequent quarrels they break, each determined to kill his love for the other ano so maintain himself as an inaividual. Eleanor goes to the apartment of John, her manager who would be her lover, but finds she can go no farther. She cannot give herself to this man because of the memory of her love for her husband. lifchael picis up the first girl of the streets he sees, ana undergoes an experience similar Eleanor's in this girl's rooms. In the end, they both return home, vowing that they will live together in love and unison, each sacrificing something to the other. 
At the besis of this situation is the theme that the love which $i$ sounded on poseession and pride without sacrifice, giving and humility is self-destructive. The brear between the two comes because each is unwilling to yield up self-hood to the other; it is only resolved by the discovery that the yielding-up must be mutual.

This selfishness is eviajenced in Michael's speech, which could equally well have been put in the mouth of Eleanor:

Every word or action of mine which affects you, you resent. At every turn you feel your individuality invaded -- while at the same time, you're jealous of any separateness in me. You demand more and more while you give less and less. And I have to acquiesce. Have to? Yes, because I can't live without you... You take advantage of it while you despise me for my helplessness.

$$
\text { ( } I, i)
$$

This cul-de-sac brings Eleanor to lie, saying that she was formerly and still is John's mistress. lifichael refuses to believe that she can love anyone else and accuses her of ajoing it "out of hatred" for him. Both set out to destroy their love, and both finding it an impossibility return to resolve the aifficulty with the wisdom gained from the experience.

$$
\text { All God's Chillun Got Wings (1925) is the story of }
$$
the marriage of a white woman, Ella, and a negro man, Jim. Their love is both tragic and beatiful, but their marriage means maness for her and utter frustration for him. 
After Ella is left resourceless when she is abandoned by her 'love 'em and leave 'em' lover by whom she had had an illegitima te child, now deâd, Jim offers to take care of her, to marry her if she can bring herself to accept him, after thinking on whet it means to marry a negro. Ella decides to marry Jim because as she says, I'm alone. I've got to be inelped. I've got to help someone -- or it's the end -- one end or another. ( I, iii)

but, in any event, her feeling of racial, superiority prevented her belonging to Jim, prevented her acnievenent of a real adjustment with her environment.

She was, however, possessive of her negro husband to the point where everything he did had to be center ea around her. She woula not even let hin study to realize his ambition, because, if he succeeded, he woula be her equal and she woula arop in her own estiration. Sre is the type of child-woman who must be the central figure, perhaps even a she-God from whom all things must come. Whe is the incarnation of the demonic feminine spirit which demands pospession even to the death or ruin of the one (or thing) possessed.

Ella's possessiveness caused Jim to suffer, to sufier with a humility ano self-abnegation unparalleled in any other of O'Neill's characters, John Ioving of Days ithout End being the orly possible exception. 
Whe trageay of Jim is, for O'Neill, not the result of his crossing race $l$ ines but because of Ella's possessiveness. All God's Chillun Got Wings, then, affords one more example of $0^{\prime} N e i l l ' s$ implicit inäi ctment of extreme possessiveness.

In Desire Under the Elms, (1924), O'Neill attains perhaps the highest peak in his use of the problem of possession. The drive for material possession ana the arive of psychic possession are intertwined, exch leading into the other.

His use of the age-old incest motif, intricately related as it is to tine Dedipus complex, has a different significance for our problem. We will fina that this play presents the larger tieme of the quest after the meaning of Iife in terms of the incest motif as it is worked, out through the frustrating a emands of the possessive spirit. Each character gives us a viation on the theme of ruin wrought in human life by the indiviauel's full subnission to the will to possess.

In Ephraim Cabot, father of Eben, Simeon and Peter, and owner of the farm, originally the property of Eben's mother, the possessive spirit takes the form of greed and self-glorifying pride in ownersip. The fam is trie symol

1. Skinner states thet o'Neill wrote this play auring the period of his poetical develoment anc maturation which is characterized by the psychical bridging of "the difficult gülf between adolescence sna maturity." In this manner he explains the theme of this play as an attempt on O'Neili's part to free hinself from the protective family ties which guara the indiviaul from the responsibilities and harsh realities of adult life. Skinner, op. cit., p. 143 and p. 228. 
of a life lived in solitude and loneliness, lacking the warmth of human love and fellowship because of the very narrowing demanas which it made upon his interests and energies. Ephraim does not recognize it as such, but he does feel that desire for possession leads hin to a near identification of hirself end the farm. He wants no other person to own what has been his.

$$
\text { ... if I could, in my dyin' hour, I'd set it }
$$
afire and watch it bum -- this house an every ear of corn an' every tree down t' the last blade of hay! I'a sit an' know it was all a-dying with rae an' no one else'd ever own what was mine, what I'd made out o' nothin' with my own sweat an'blood! (II, i)

The ritiating effect of extrene possessiveness here speaks for itself.

In his will to direct, even dominate, the entire life of his sons we find the transition of desire for possession from inanimate to a nimate things. Ephraim has kept his two olàest boys cowed in spirit end stunted in ambition by dominating their very thoughts. Fe has instilled in them his desire for the farm as an object of terial possession but not as an inherent part of their beings. Fear is mingled with their desire. With Eben there is more resistance. 'He, too, desires the farm, even more intensely than his half-brothers, not, however, as material eviàence, but as a connecting link between himself and his mother whose early death he believes was caused by his father's haraness of spirit and severe demands upon her physical strength. 
Dben coula not give full strength to the resistance of his father because of his àeep-lying fear of him.

With the third wife, Abie, Ephraim still makes the demands of full submission to his position as possessor. She has come to his "hum." She is his wife, the new mother to his sons, and the mistress of his holisehold. He fervently desires that she bear a chila so that the farm can be inherited by his flesh ana blood.

In all his struggle to feel himself fulfilled by complete possession of the people ana things about, Ephraim never reaches the place where he is contented. Why? Because, says O'Heill, the spirit of possession kills if allowed to go unchecked. At the end of the play when Abbie and Eben are taken away to prison, the frustration of Ephraim's life is complete: "Ionesomer now than ever it war afore... hard and Ionesome." (III, iv)

Eben's Oedipus complex arives. him to seek to avenge his mother's death, which he believed was caused by Ephraim, his father. Ae feels that by gaining possession of the farm he will displace his father ana thereby re-establish his own primary relationship with his mother -- a variation of the incest motif.

1. The incest motif as it cones to us from Green literature ana from psychoanalysis as the dedipus comlex "is libidinal desire taking the form of unconscious desire for sexual satisfaction with the parent of the ooposite sex." Eealy, Browner, anda Bower, op. cit., p. 148. 
With Abbie, his step-mother of his own age, ambivalence 1 of emotion is supreme. He is sensually attracted to her; he recognizes her as a mother-substitute and is revolted by her attraction for him. Eventually with Abbie, his Oedipus urge is realized. Ee makes her his own, therein displacing his father as real possessor. Even before this union, Eben has attemptedto replace his father with an object-choice unrelated to his mother -- Min, the local prostitute who has previously been visited by his father. O'Neill anticipates the final outcome of the play in the following scene between Eben and his brothers after he has returned from ifin's house with the news of their father's marriage.

Simeon: Iin'a nake a true faithful he'pmate! Eben: What do I care for her 'ceptin' she's round wa'm? The p'int is she was his'n -- an' now she b'longs $t^{\prime}$ me! An' Min ain't sech a bad un... Wait'll we see this cow the old fuan hitched $t^{\prime} !$

Simeon: Mebbe ye'Il try $t^{\prime}$ make her your'n, too? Eben: $\quad$ Eer -- here -- sleepin' with him -- stealing my haw's farm. (I, iii)

The sinful and guilty death which is the outcome of Eben's bitterness though mitigated somewhat by the eventual realness of his love for Abbie strikes once more the note of the danger of too extreme a possessiveness.

1. In such cases of love-hate ambivalence the attraction of of the love-object satisfies the libiainal impulses of the inciviaual in a complentary fashion, while the feeling of hate is a roused against the same object in the Ego's struggle for its inciviauality. 
Abbie Putnam as a character study of a woman àriven to destruction of self ana of the things she loves by the desire for possession is carefully aone. In one of her first speeches in the play, Abbie clearly aefines her situation. She says:

$$
\text { is woman's got to hev a hum! (I, iv) }
$$

The importance of this statenent lies in the wealth of meaningful emotions of women associated with the word "home." Abbie looks upon a home as not merely shelter ana security in the physical sense, but also as a spiritual anchor. In making a home she realizes the ultinate purpose of her existence -- the creation of a state of reciprocative physical and mental complementation.

It is true that she knew her marriage to the old wan coula not bring fulfillment, but she sees it as a neans of builaing toward the realization of her desire. 'the possession of the house and farm is the first of "what was due (her] out of life." It does not take her long to realize that Eben will serve as the means for all further satisfaction. Not content to be only partial possessor, she makes Eben hers, too -- to be more than ever the means of her possessive end. She covers her evil intent by playing upon his love for his mother in telling him that he is avenging her. Her ulterior purpose is fulfilled when he gives her a son to to inherit the estate for her at Ephain's death. In the end, 
Abbie, in her aesire to possess, has brought about her own aestruction and that of the objects she loves -.. her child anō Ẻben.

The final note of the possesive spirit is sounded in this play by the sheriff when, upon looking over the farm, he says enviously:

It's a jim-dandy farn, no denyin'. Wished I owned it. (III, iv)

The Great God Brown (1925) is largely concerned with the problem of the creative spirit but the present problem receives considerable treetment as an aspect of this, its primary theme.

The characters are used as foils for one another. Dion is subjective, sensitive, ernotional unstable; Billy is selfassured, callous to a degree, anc objectively practical in his associations. Nargaret is the symbol of the possessive, maternal female. Cybel is $r$ epresentative of the earth-mother figure, calm, understanding and dispassionate. Each of the characters finas his own personality so restricteà by externalities that he is forced to show to his associates a nature greatly foreign to his real one -- thus the use of the masis, representing the diverse personalities. Billy Brown, in the opening scenes of the play, wears no mask because he is the type of indiviaual of normal intelligence, selfassurance, ana not too much sensitiveness who can face the 
world as it is. Dion, on the other hand, while really being "spiritual, poetic, passionately supersensitive, helplesslJ unprotected in (his) childike faith in life," wears as his outwara neiture a mask, the expression of which is "mocking, reckless, defiant, gayly scoffing and sensual." It is his defense agdinst the realities which are too much for him to face. Nargaret is depicted ss an intelligent young girl with a drearny expression. Cybel has a mask of the prostitute which she wedrs for the world. The failure to make satisfactory adjustment to reality causes both Dion ana Billy to seek shelter in regression to maternal protection. O'Neili has aeoicted their regression in terns $O I^{2}$ contrasting elements of the masculine spirit, the subjetive sensitiveness of Dion on the one rana ana the objective practicality of Billy Brown on the othei. Wion is thony's whole life is centered around the mother-imago -- in nis early relation witi his own mother, in his first love for Largaret ana, later, in his deep affection snd need for Cybel. Since his mother was the only one who, in his chilahooa, could keep from him the too stark realities, he sought her likeness in all his women associates. After his mother's aeath he says:

-.. I was tho sole aoll our ogre, her husbana, allowed her an she played nother and chila with me for many years... until at last I watihed her die... Anâ I felt like a forsaken toy anà cried to be buriea with ner, because her hana alone caressed without clewing... 
Dion transferred his aepenaence from his mother to his wife, iargaret, who became"three mothers in one," but whose poseessive maternalism soon forced him to seek unpossessive motherly protection in Cybel, the prostitute. In his first love for liargaret, jion felt that he had found the strength and the protection which he needed to face the worlà. Later, aster their marriage, largaret became more than his protectress; she was like an octopus whose great embracing arms bruised and suffocated him in their hola. Her possessive love forced him more anä more into hime elf until he coula not resch out to her, nor she to nim. has the other's izey.
(I, i) This is one of the biggest trageaies which o'Neill presents to us -- the utter lack or sympathetic understanding in the intirney of aeeo love. It is a lutile striving towara a realization which cannot be achieved and which ultimately destroys those who seek too ardently. Margaret cannot recognize the ceal Dion beneath the masir of Pan even when he at last, knowing that they must fully realize each other, removes his masit and implores that she see hin as he is.

....Beholà your man -- the sniveling, cringing, life-denying Christian slave you have so nobly ignored in the father of your sons! Iook! (Hetears the mask from his face, which is radiant with a great pure love for her and a great sympathy anc tenderness) 0 woman -- my love -- that I have sinned against in my pride anà cruelty -- forgive my sins -- forgive my solitude -- forgive me sickness -- forgive me! 
Wargaret does not comprehend; she thinis her Dion is dead; and he is, for he is utterly lost to her because she cannot understand. Dion leaves her, fully realizing the futility of this, to him, torturing and painful relationship.

It is only with cyoel, the symbol of the calm, wise, unpossessive earth-mother, that Dion finas peace and comfort. With her he does not need to mask. She knows him for what he is, anả she offers him the kind of love he needs -- giving anà unảemanòing. She makes him happy anä gives him strength in her unselfish frienasilp.

The symbolic death of Dion is in part the result of the life-negating effect of Nargaret's over-possessiveness. Margaret, the symbol of "the eternal girl-woman with a virtuous simplicity of instinct, properly oblivious to everything but the means to her ena of maintaining the race," finas, in her love for Dion, the gratification of her wifely ano material instincts in using him as the means to her ena. Wheir marital maladjustment lies in the fact that largaret made Dion seconóary to her role as wife and mother instead of admitting him into full partnership in the creative union. She constantly views him as her boy, her cinila, forgetting the fact that he is also her lover.

1. Quinn, Arthur H., History of American Drama from the Civil War to the Present Day, Vol. II, p. 192. 
Here, once more, O'Neill points out the evil results of extreme possessiveness; with the difference that the man (Dion) first seeks protection as of a mother ana then, when this relationship becomes nore all-consuming than sheltering, is forced to seek elsewhere a love that will not consume him.

In Strange Interluae (1926), the main focus upon our problem is given in Nina's drive to possession. The daughter of a college professor, she is the unifying character of the play. She loses her fiance, Goraon Shaw, shortly after he goes to war as an aviator. Her puritanical father, motivated as muci by his possessiveness of her as by his moralistic sense, has prevented the consumation of their union; this precipitates her decision to compensate by leaving home to become a nurse. She goes to a veteran's hospital where she gives herself to the wounaed soldiers -- to give them happiness ano in search of satistaction for her vaguely comprehended, but persistent, libiainal urge. Driven on by this force, her life becomes entanglea with the lives of many men, for, for her, no one man is enough. With desires that can never quite be fulfilled, held in check by inhibitions, àriven onward by her libido, ina is the "incarnation of vitality, a creature that is ariven to medale in the lives of others that her own life way be fillea to the overflowing":

1. Clari, Barrett ., Eugene O'Neill, The Ian gna His Days, p. 175 . 
It is through her thoughts concerning the child that we have one of the clearest statements of the possessive feminine spirit which, as it works through Nina, blights the Iife of every man intimtely associated with her. Hina thinks:

Shoula I have tolà (Sarl)?...no... my own secret... tell no one...not even sam... Why haven't I tolà him? ....it'a do him so much gooa... he'd feel so proua of himseli...no... I want to keep it just my baby...only mine as long as I can... well, I do feel happy when I think... and I love Sam now... in a way... it will be inis be by too. (III)

In the end, vina, having exhustea her huebinā, her lover, ana her son, not to neatioi herself, turns et last to "dear ola Charlie" -- the tgo of chilaish weakness in the male. In Dynamo (1928) the need of nan to be possessea is. once again useả. Reuben, the principal character, almost completely carries the theme. Fis impulse is to break his 010 ties and to leave home -- to give himself over entirely to externals -- springe from his mother's betrayal of him to his stern zuritan father. After a year away fron home he returns, a colà, hara, aggressive materialist in all things except his longing to see his mother, who has died meanwhile. The inowledge of his mother's deatn only intensifies his longing for her. In this situation olieill has given us one of the elenentary sex relatioushins besed on the Oedipus complex -- the woring out of a son's life in terms of mother fixation. Feuben, as a boy anci man, never is complete as an inaiviaud becaue of his strong a eo enaence on meternal protectios. 
In his first relationship with Ade he sees in hei a reflection of his mother, supplemented by her objectifiction of serisuality ano external a esires. See is the challenge of Iife to be won and matered, but he cannot face the challenge, dependent is he is upon his mother. Hever, even in his fullest scientific objectivity, hoes he lose his gen raing to we that which he thinks his mother would have hin be. We realize, $O H^{*}$ course, that the secret of life is the dominant theme of this play, out the searcin is so airected by the mother symbol that failure to recognize the importance of the oedipue comples here leads to the pelief that the play is entirely one of soixitual seeking for a sybol of peith outsiae ran himself as objectified in electricity as God. Towever, Jiveill's play is not so rar renovea frow comonplace reklities as it may seem. An bries surve of psychowalytic therapy will reven countlese numbers of cases of men ariven towád sone vágely conceiveá pal by their regresive tenóncy of infentile orientation to reality in terns of the lack of inảiviazl responsibility 1

in neternal protection.

1. In frevaian teminolog, this wish is snom as the regression to the state ot intrauterine existence, at which tine the inciviaual is entirely carea for and protectea, no denenús being made upon his energies. 
As the play progresses keuben's yearuing for his mother, for a means of comunication with her, becones an obsescion. Iis knowiedge of the unatromable powers of electrical nhenonena lea as him to hove the through them he can reach her. He says:

...I'd like to reach her sowehow; no one knows what happens after death -- even science aoesn't -there may be sore hina of hereafter... Bunny, that hunch I got when I was talking to Ada... About praying to electricity, if you knew how...it was like a message... Kother believed what I believed when she diea... maybe it cene tron her... aw, that's just superstitious juni... Dut what is it?... Iook at how mysterious all tin is electrical wave stuft is in $r s a j o$ ano everything...that's scientific fact... ana why coulan't soriething like that no one understanos yet?... between tire dea à and tre living?

(II, ii)

Because of this obsession the icentification of the aynamo with his mother is an exsy step. The mysterious power of the dynamo is god-like; it is something like the love of a mother,

...a great aurk mother!...that's what the dynamo is! (II, iii)

Then the idea comes to him of praying to the aynamo, to petitiou forgiveness from his notiner, the dynamo. He prays:

Oh, liother of iffe, my nother is dead, she has passed back into you, tell her to forgive me, and to help ne fina your truth! (II, iii) 
As time goes on the obsession becomes more anà more dominant. Reuben feels it necessery to give up his love for Là because it makes him impure in the sight of his $n \in w$ nother-image, the dynamo. In his search for purity he fears Ada ana shuns her; she awakens in him all the old sensual feelings of their first union. Whis cannot be in view of his mother-fixation because the mother has double hola over hin as a symol of authority ana as a love-object. Contact with saa is a sin against his new love-object. his failure to find satisfaction in his mother worship nakes him wonder:

laybe she feels I haven't killed all desire for Ada yet?... that I ought to face her and conguer the flesh once for all...

He puts hiaself to test:

...I'm going to kiss you, Ada -- just once -only isis you -- she wiste me to - as a final test -- to prove I'm purified -- (He I00ks up at her now and lurches forwer with a mosn of passion and takes her in his arms... He kisses her trantically.)

(III, ii)

He has failea; "he groans anò beats his head against the floor."

Lother! ... I've betrayed you... you will never bless me with the miracle now !... you have shut me out of your heart forever!

(III, iii)

He kills fada, calling her a harlot, as his own mother had done, ana then rushes to the ànamo where he grasps the carbon brushes, short-circuiting the current through his boày. "There is a flash of bluish light ajout him ano all 
the lights in the plant aim... ano the noise of the dynamo dies until it is the faintest purring hum," his voice rising "in a moan that is a mingling of pain and loving consummation." It is Iike the crooning of a baby as it is àrowned in the crescendo of the dynamo's hum.

The character of Reuben is replete in tine chilaish regression to the intrauterine existence, the blissful state of "prenatal existence (thet) is nomally supremely pleasurable." 1

Reuben's moticer, Arelia Iight, had sublimated a large part of her libiainal cathexis in her love for hor son -the object-choice for realization of ambition on the part of many women. Ler jealous possessiveness of the boy, however, proves to be her undoing because of the rebellious tendencies of enotional weaning which she arouses in him in his attempt to estabish his inaivicual zoo. She is O'Neill's representative of the type of woman whose possessive love is destructive of its object. Fers is too great an emphasis upon the tenacious holaing of another indivicual within the bounas of a selfish emotion. In every instance where an Neill character givee way to his possescive arive, the object-choice is either thwarted or destroyed.

1. Healy, Broiner, Bowers, op. cit., p. $1^{r} z$
2. Supra, Introauction, p. ii. 
The problem of the possessive spirit is the central theme of Hourning Becomes Electra (190I). Throughout the play the arive of Lavinia to possess that which ner mother, christine, has is predominant. After she has cost her mother her lover and her life, she strives to get away from the possessiveness of her brother for whose love she had once been a rival. Ana since he will not allow her to escape him, she finally drives him to suiciàe but not before he has left some eviajence to noison the mina oi the man she was to marry. Ifvinia's arive or possessiveness, based on an Electra complex, is clearly siretched in the following dialogue between the two women:

Christine: Whet a fraud you are, with your talk of your fether ana auty! on, I'm not denying that you wat to seve his pride - Ena I inow how anxious you are to keep the farnily from more scandal! But all the sane, that's not your real reason for spering me!

Iavinia: (confused - guiltily) It is!

Christine: You wantea fäan Brant yoursels! (Brant is the mother's lover.)

Lavinia: That's a lie!

Chistine: And now you know you can't have him, you're aetermine a thet least you can do is taise inim from me!

Lavinia: No!

Christine: But if you told your father, I'a have to go anay with caam. He'a be mine stili. You can't bear thet thought, even at the price of by aisgree, can you? 
Iavinia: It's your evil minä!

Christine: I know you, Vinnie! I've watched you ever since you were little, trying to do exactly what you're doing now! You've tried to become the wile of your father ana the mother of Orin! You've alweys schemea to steal my place!

(Homecoming, II)

O'Neill's use of both the Oeáipus anà Electra comlexes in tris play shows the emphasis he is givine to possessiveness since both ärives are primarily possessive by nature. Io want what someone else his is of the essence of both arives. The central figure, Lavinia, whoee love for her father ais hatred of her mother carries most of the action throughout the play is completely dominated by tile slectra complex. In every action she is seeking to displace her motrer in the affections of three meil who represent the need for husband, lover and son. Whet she does not succed in aisplacing those affections, out only wrecas the lives of all conceneả, including her omn, is the trageay of the play, a tregeay which has its basis in her over-weening possessiveness.

Lays Without $\underline{\text { Wa }}$ (19e5) is the story of a man aivided geinet hinself, the two personalities shown as two stage characters -- John, the real self, anä Loting, the bitter, àerisive, àisilusioned self. The other characters are unaware of the two persons; they think it is John speaking in cynicism and aisillusionment. At the 
end of the play when John surrendexs to the love of the Crucifiea Christ, Loving dies and John becomes a unified personality, John Loving.

Iis Wife, Elsa, is the outstanding O'deill character for whon comlete poseession meens unlimited freedon. Both in possessing John and in being possessea by him she feels that her aim in life is fulfiliea. Sne, especially, of all the romei characters hes integrated the four aspects of wornan's love -- that which sine bears towarà iather, lover, husband, and chila.

To concluae our aiscussion of Jeill's ase of the probIen of the possessive spirit, we shall sumarize the points that have been made in the treatments of the plays concerned either partly or almost wholly with this aspect of libicinal cathexis.

We can say with certainty that $0^{\prime}$ Neill's answer to the question: "Does extreme possessivenese justity life or make it livaple?" is emphatically negative.

The outcone of every play anglyzed in tin is cheter with the exception of The Straw, Enna Christie, Welaed, and Days without End is imeaiately or by implication tragic;

1. Freaá, Sigmund, Psychologe of fomen, pp. 182-18z. 
and this outcone finds its source, its motivation, as has already been inaicated, in the extreme possessiveness of one or more of the characters involved. Only in Gola and in Desire Under the Elms is the arive for material possession at all paramount; the other plays are conceried with posession as a channel for libidinal forces. Even these two plays largely given over to the greed notif are marked by the blighting or ending of the lives of those who are infected with this exteraalized form of extreme possessiveness. This series of catastrophes hinging uoon extreme possessiveness amount to an inaictment or it. o'veill does not say in any place that it is evil but by demonstrating the evilness of its consequences, he actualizes his belief that this is one Dehavior-pattern thet is not the answer to the question, the opportunity of life but rather its refusal. How, whether this was or was not a conscious purpose of his in the writing of these plas is a question that is beside the point. Here, in these plays, we have di scovered content that is nuch above the level of the merely sensational; content that it would be impossible to fina in shocking or obscene literature whether aranatic or of other kinas. We have already discoverea, we believe, the intinate connection between o'Neill's use of sex problems and the action and characters of his plays. 
In the four plays, The Straw, Anna Christie, Welded, and Days without End, we have suggested a positive answer to the question of how life may be justified, how it may be nade livable? ana this positive answer will be treated more fully later on. 
Chapter Two

The Problem of the Creative Spirit 


\section{Chapter Two}

The Problem of the Creative spirit

To common sense, it may seem that the sublinative or secondary channels of Iibiainal cathexis involved in the problem of the creative spirit are unrelated to sex. While no such gap exists for the psychoanalyst, it is true that instanoes of this particular problem are more freauent End more obvious in usual Iife areas that was true of the problem discussed in the preceding chapter. For this resson, by consiaering this problem, we should come mach nearer to ascertaining $0^{\prime} \mathrm{Ne} I I^{\prime} \mathrm{s}$ answer to the age-old question, 'What is the metning of life?'

This problem involves such sublintive channels as artistic endeavor, chila-bearing and reariug which may be considered peripheral to the normal channel for libiainal energy. Iore covertly sexual is the desire to belong to, to have an ioentification with, either a group or some natural external force.

The closing of such secoláary channels, tine frustration, of the creative ana procreative arives may have as cruel ana as blighting en effect on tine inàiviaual as the airect repression of the libiainal arive itself. The effect of the death of a child, whether causea by the physical incapability of the mother or by artificial meens, is an excellent example of the way in which the failure of these less immediate outlets can build up a sense of 
incompleteness in the inaiviaual thus afflicted. O'Neill uses this symbol of the dead child meny times to represent the frustration of the crective spirit.

\section{2}

The couple in Before Breakfast had marriea as the result of a chila conceivea out of weàlock. The stillbirth of this chila symbolizes both emptiness of the union, more concretely brought to the fore by the bitter recrimination Jirs. Rowlana visits upon her husband, ana the failure of his creative spirit. The suiciae of the husbana as a means of escape from the constant ana harrowing shrewishness of his wife may be taken as an instance of life's negation by seeningly invincible forces. Femmed in always by the vocal anö consuring possessiveness of his unsympthetic - spouse, Alfreả, woula-be writer though he is, finds himself unable to enjoy or find meaning in life. The suicide, anticipated as it is by the child's desth, is a tragedy that has its root in ine inability to create.

$$
8
$$

In Beyond the Eorizon, the transference of roles between the two brothers at the behest of the girl frustiates the creative element in both. Robert, the areamer, caught by the fascination of far pleces, stays at home and becores a farmer, trying to persuade himself that what he had

1. Cf., the figure of the dea chila in The Fog (1914), Before Breakfast (1916), The Tirst in (1916), Beyona the Horizon (1918), Desire Unâer the Elms (1924), aná Strange Interiúc $(1920)$.

2. supra, p. I

3. supra, p. 2 
always been seeking was here close-at-hand, under his doorstep as it were. Andy, the practical man, nade to bring life into being from the soil, goes away voyaging to South America in Robert's place. After his return, Robert says to him:
... Jou're the aepest-ajea failure of the

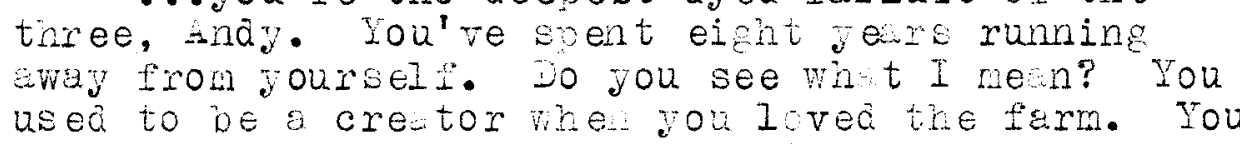 ànă lize were in hamonious petnership. fnả now--... gambling ril th the thing you usea to love to create proves how far astray -- So you'll be punished. You'll have to suffer to win pack --- (III, i)

Whe aesth of Robert and unts child late in the play is another symbol of the deady effect of this wisplacement of the two brothers. Rovert's physicel failing un fint death unōer trie uncongenial burāen of farm work has a similar meanine. This psychic anc physical ruin is primarily causeo by the overvening possestivenss of futh; but its seconowry root is certainly in tre feilure of the creative spirit.

In line straw, Stephen urray's recovery from tuberculosis, inciantal to the tiene ol his relationship with Eileen Carmoay, is a result or the price engenderea by his success at creative writing. The return of the aisecse some nontis later, when Jurray is without tine happy

\section{Suora, p. 5}


stimulus na encouragement of his earlier companionship With aileen, nay be considered at least vartly caused by a slackening of his crestiveness. Fere is illustrated the close connection betveen an inaiviakl's euccessful realiztion of his creative crive end his well-being.

The major thene of Gold is greed, as we have shown in a peceding ciapter. But, by implication, the effects of this servitude to the uncreting and life-negating lust IO golc nay be attributed to tre misairection of the creative spirit. Deâicatea as it is in this pley to an end the nerrows retner than enlarees the oseibilities of life, the ruin wine a egeneration of the cantain's family are an inevitajle result of tire captain's misaplication of his creative energies.

A major motif in Anna Cristie is the sense of velonging to the ses which is shared by all three of the lesding characters. The uninapy experiences that had been hua's prior to the time covered in the play were partly due to her having been torn avay from what was her natural elenent. The suggestion st the end of the action that she, with irat, will be able to work out a

1. Supra, p. 6 
socially acceptable and happy Iife is nade possiole by the fact that the ir home will be on and of the sea, love and fear of which is common to them both. Anna, having thus found her home olace, can buila a happy li ie for herself anả her sailor lover.

In The Pirst Inn, the resolution of the couple to have no nore children, partly as a remorial to the two chilaren who had died earlier, and partly to enable the wife to accomany the man on his anthropological expeditions, is finally broken by the wife who tells her husban, as he prepares to go on a five yeur journey, thet she is to have another chila. Whe theme here is the partial acceptance of life in the delayed realization of the creative spint brought about through the iulfilment of tine reproductive urge. The attempted negation of life involvea in the vow to revere unaimmed the memory of the dead chilaren, symbolizing the sustration of the creative spirit, is thwarted by the necessity of the feminine ideal to satisfy itself in the creation $0:$ new Iife.

But the woman wins out over tinis negation, largely produced by the possessiveness of her husband, who wants all of her for himself. Ana thougn in giving lifte to ner crection, sine dies, we may velieve that o'veill wished the living chila to stand foi the triman of tie creative spirit even in the face on the creator's death.

1. Supra, p. 10 
The 醁y Ape (1921) is almost wholly deroted to a study of the frustration of the creative soirit. It is the story of a soul that seeks to escape. or to aeny the elan vital, of a soul in conflict with iteelf and the worla about it jecause it cannot belone.

Yank, at first, is comolecent in the knowleuge that he furnishes the power which "moves the woiks." He sees hicself as the creative force itself, ana glories in this feeling until he is suddenly aispossessed of it by the cries of the uper-class girl, Miladed Douglas, who wh en she sees hin shovelling coal in the stoke-hold is filled with horror and terror.

Take me away! Oh, the filtry beast.

Her very attitude anä ap earance upset Yank's complacency and brear his pride. After this cataclysmic experience, he tries to "tink." His fellow stokers jibe him about falling in love with the girl from above aecks. He mutters:

$$
\begin{aligned}
& \text { Iove, hell! ... Jate, dat's what I've fallen } \\
& \text { in -- hate, get me. }
\end{aligned}
$$

Fe cannot understana this feeling of chaos that beäevils him, which has robjed hin of his pride in being at the bottom and which nakes him belong nowhere.

1. It must be unảerstooo that the cre tive spirit aoes not imoly procreation tilone. It carries nuch larger implications of man's $\mathrm{s}$ bility to mere for himself a place in life satisfactory to himself ana to the power outside him which arives him on. 
Yanz does not see in his love and hate for this woman he can never possess the aesire and the thwarting of the creative spirit. Is we take Yank ana Hilärea as representatives of the masculine ana feninine essences, we can wore esily unāerstana Yank's emotional uoneaval. In the conflict of the masculine and feminine spirite we can fina a partial explanation of Yank's feeling of being aârict, of belonging nownere. Without the possibility of realizition of the funamental purpose of life he has nothing to live for. The feminine spirit is inaccessible; it can never come into union with his, ane his purpose is. defeated.

This is basic to Yanin' $\mathrm{I} e$ eling of insecurity as revealea in the scene at the zoo. Yank feels a kinship with the gorilla an speaks to him:

1. Guinn states that "Yank, the stoker...represents force, which if unguided may wreck the worla, but out of which all that is sienificant nust grow... [O'Neill] is showing the struggle of alloient man upward and endeavoring to depict in terms of modern institutions tice terrible struggle through which the rece went, in beginuing the orocesses of mental growtin... Ililared Jouglas... stirs in Yank the aesire for something of which he nad not areaned." Quinn, on. cit., p.. 185-134. It seems that the interpretation of the "force" and the "something" of which Quin soears in terms of libiainal cethexis gives a much more comprenensible picture of this play tian does the use of his very vegue, anbiguous terms. 
It's ais way, what l'm arivin' at... you'se can sit anc dope ciream in ae past, green woocs, de jungle

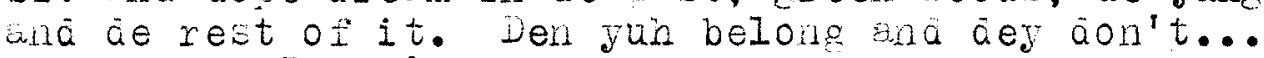
But ne, - I ain't pot no past to tink in, not nothin' aet's comin', on'y what's now-- and at don't belons... Yun can't tink, can yuh? Yuh ceir't telk, heider: But $I$ win ne he bluffet talkin' ana tinkil' - a'nost get eway witr it - a'nost! - and dat's where ce joker cones in. I ain't on oith anó I ain't in neeven, get mer I'm in ae micile tryin' to separate' em, taking all de woist puncies from bot' $\mathrm{O}^{2}{ }^{\prime} \mathrm{en}$.

$(\nabla i i i)$

Yank cannot escape tine tragedy of b ing dorn a man who cen think ana feel, but whose thinking ana feeling are pur ose1

less. ha, in the end, he escapes by entering the cage aná being crushed to dectri by tile gorilla.

line olay is without a single gleam of hove tret this wen can ever find himself so as to julfill his jurpose the creation of life. Yank's traged, based as it is on his failure to fina an outlet, to belong, is one of o'reill's clearest inailations of the weed of fulfilling tre creative arive. It is an implicit nrotest ag inst any system which nakes the lowly worker a naneless cog in the maciline.

I. Cf., Skinner, of. cit., p. 112 . 
The fountain (192I) hinges on the cuest oz Juan zonce de Leon to find out "why have L lived?" As a joung nan he is the ambitious thinker snä hard actenturer, in midale ape he is the tolerant thinker, and as an ola man he is decidedy the rowantic areaner, seeking to restore his youth througin the spring of Life oecause love hes come to hin.

As a youtin, Juan is the unwilling recipient of the love of Ifria, wife to his friend, Vincente. When laria, who is older than te, tells him of her love, he esks:

Why must you ruin our rare frienuship with a wora every minstrel mouths? . . We pretenó love alone is why we ive... wite is nobler than the weak lies of poets - or it's nothing.

Later, Jukn leaves the Spanish court, comes to the New ronld, as Governor of zuerto fico, he is kind to the natives and the a arocate of justice. Fe is restive unaer the a elaged arrival of his patent for explortion, the royal permission he neede to nake semen fo: the fountain of Youth which Nano, a captareo Inäian, has tola him of. Bewtriz, haughter of haria, now wri to Juan, cowes from Spain. A rebellion against uan is cuietea only when he tells the solaiers and sailors that they sail on the norrow. 
Before leaving, Juan ezacts from Beatriz the promise that sice will not marry until he returns or she hears 0 his death -- hopeful that he will cone back the aouble to the joung Ponce àe Ieon whon Beatriz's mother knew -- the strong, courageous, nojle man. Ie goes off to fina tine "Spirit of Youth, Eope, Ambition, Zower to ärearn anä dare." His voyage is fruitlese. Iano betrays him to the Indians who leave hin for dea by the spring a d a then wipe out $h$ is followers. Fe is found and taken to the coast by Iuiz, his friend. Beatriz comes to nurse him and orings With her his nepirew, the àoule Jual had hoped to be. It is only when he brings hinself to give them his blessing that the full significance of life acwns upon him. He blesses them, sacrificing his own for their happiness. "You of this eath -- love -- hail -- anc fareweli! Go where Beauty is! Sing!" (xi) Juan Iistens in ecstasy to the fountain song which has cone to wean the eno of Iife tor hin.

Love is a flower Forever blooming Besuty a fountain Porever flowing Upwa in into the source of sunshine, Upware into the azure heaven; One with Goo but Ever returning To kiss the earth that the flower neg live. 
Sex has a very minor role in this play. It is important only as a contriuutive fuctor to love between a man and a woman and as a differentiation between the masculine aná feminine views or life. For the women, as Haria so clearly shows, love is the essence of life. For the man, there seem to be greater things until ilfe is goine and wi th it t:e realization that it has been empty because it containea no Iove. It took Juan Fonce ae Ieon until his death to fina that early in life he spurned the one thing thit can maze life worthwile -- self-sacrificing love, for man is not sufficient unto himself alone. 1

The Iinal scene of ielàed holas the promise that Eleanor owen ana Hichael caje, its chief figures, have found the means by which tiney can solve the problen of possessiveness and maize their relationship one which fulfills rather thin negates life. In a somewhat symbolic sense, this problem of building a successful marriage may be considereà a creitive one.

As sictched in the previous chapter, the two quarrel over the possessiveness of their love which seems to a enend too much of their individuality. They break with one another, and go forth in an attempt to kill their love by provisional unions with other people. This tiey cannot ao; the nemory of the other's love holds them back ana trey return to each other. 
The prostitute lifichael had gone to taught him that one must love life in orảer to find love in life. She tells him:

You better best it home... Stick to her, see? You'll get over it. You can get used to anytring... You'Il go back no matter what, and you'Il loin to like it... Iiss and make up. i'erget it. It's easy to ferget -- when you got to... (II, ii)

Hichael learns

... to love life -- to accept it and be excilted --
that s the one in left to us.

When he reaches hone, he fincs his wife there. They vow to "live life to each other" through love, not through hate.

(They stare into each other's eyes. It is as if now by a suaden flash from within they recognized tinemselves, siorn of all the ideas, attitudes, cheating gestures which constitute vanity of personality. Iverything, for this secona, becomes simple for them -- serenely unouestionsole. It becones impossible that they should ever deny life, through each other, sgain.)

ONeill leaves them in the affimation of life through self-sacrificing love. Thas have the Canes solved the problem of creeting, of building a life that is developmental rather than deadening. 1 All God's Chillun Got Wings is a tragedy of frustration for the white woran, Dlla. The negro, Jim, suffers to an extent hardy paralleled in any other o'Neill play but his acceptance of the terms of his life, even the 
final insanity of Ella, is in a sense heroic, a successful even though half-defeated meeting of the problem of existence.

The death of Ella's illegitimate child and her unwillingness to have a chile by Jim is a clear symbol of the frustration of the creative spirit. Ella had marrieà Jim bectuse as sine says,

I'm alone. I've got to be helped. I've got to help sorneone -- or it's the end -- one end or anotiner.

Ella accepteà marriage witi Jin as "one enả or another." She tried to feel neturally proud of her negro spouse, to accept him as the man who was her husoana, but there was a burrier she could not hurde. As long as she could be with him as a sister with a brother she coula bear the stigma of a mixed mariage. Sne sougnt release in isolation which nade her "more nervous anu scary, always imagining things," (II, i) and which gave her no release from social ostracisn and no relief from the loss of the feeling of superiority of race.

This failure of ElIa's to fina all outlet for her energies, or to find a way occepting the terms of her life with the negro, Jim, is the aifficulty which orings about her eventual loss of reason. O'Neill coula harày have found haw sher means of à emonstrating the vital need of the creative spirit ت̃or fulfillnent. 
1

In Desire Unaer the Elms, the Iong servituoje of the father, Ephraim, to the acquisition of possessions brings him nothing in the ena but lonesomeness. His lize is enpty because he has never createa.

3ut oreill does not close out the chracter of Eben ou the sane note of comlete erustration. whe chilà tboie bears in is the realization of his urge to create even thougin it is uItimately aestroyed. Anā, moreover, Aobie has become his complenent, the being whose vibrations fit into his as öo the cogs of a gear --- constantly siliting, yet ever interlocing. His union with bbie gives him a new attituãe towarä his father. He is tolerant of him nom, pessive in his resentment, ana secure in the knowleage that he is the real possessor of everything once belonging to his parent. Eben reaches maturity of mina through his emotional ina encuance of his father and his love for Abbie.

There is no conuemation of zben as a character even though he has committea the heirous sin of adultery in incest; neithen is nis character couanea. Father he

\footnotetext{
I. supra, p. 14

2. Te see in the a eath of this chila of selidish love the frustrition of the crestive spirit through veo-cetheris wete the elf rersoute the direction taten by the entire libicial energy.
} 
exemplifies what happens when men are bound in hate to a thwarting entronnent where the only chance for release is througin unlawiul, sillul channels which bring ruin in their waise unless counteracted by the inaiviaul's spiritual regeneration through love aida sel̈̈-sachifice. When Eben has sicnea the whole gamut of sins, paychologicelly spejing, his salvation is secured by his final gesture of self-sacritice in giving his life to sboie as companion in her guilt. He has loved with a love unconfinea by his own Ego, therezore, even though untimely and guilty deth is his inferrea end, his life has not been empty and useless decause he hs given of himselit to another. Itarco Ifilions (1925) treets of tine problem of the crestive soirit in symolical terns. Marco 2010 is the symbol for the nan whose potentiality for living a complete life is etunted ano fincly killed by the aevotion of his energies to the materialistic, the lipe-negating.

Fis potentiality is incioted $D$, the poen he had written his sweetreart, Jouata, as a boy but as he passes through country after country on his way to Cathay, we see this quality of 'boul' aliming more and more into the becigrounc. 
Kukachin, symbol of perfect love as she is, is also representative of the auimatiug element; if larco had ever seeil her por whet sine was, he would berforce have begun livine creatively. Jonata, on the other hand, stanas for what deacus rather thin enlivens: ana Marco's Faithulness to ner, such as it is, toifies nis inebility, even his unillingness to find an outlet for his creative impulses.

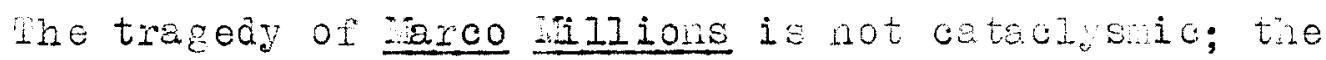
weeniag away of hat was tine in Marco polo until he pecones a "swag idol ef etuffed selz-atisfacton" is eradual. Then, in is lest look into Lubacin's eyes, he alnost gorgets nimself, he is stopped oy overhesring the word--million. This is the ena for him as a living person; thereater ne might as well be dead.

o'Neill has laia pare in his treatment of Tarco Dolo the unloveliness of a person who has throw awoy his crestive energies, his capacity for unselijsh love. Ana the triumph of Lukachin, ouilt upon tre ia 1 depth ana unselfishness of her love, all the more heavily emphasizes liaro's failure, the failure that must be the lot of all those who disresara the creative impulses.

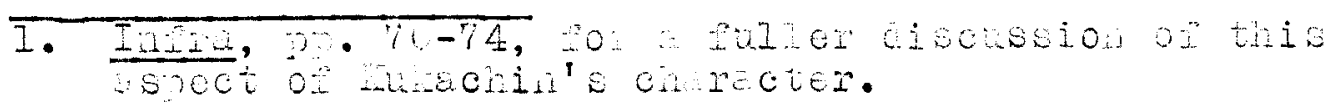


1

The main theme of whe Great Goa Brown is given in

this statement of Dion's:

I've loved, lusted, won and lost, sung auci nept! I've been life's lover! I've fulfillea her will eno if she's through with me now it's only because I was too wesk to dominate her in turn. It isn't enough to be her creature, you've got to create her or sise requests you to destroy yourself.

$$
\text { (II, ii) }
$$

The failure ot each of the characters is the failure to create life while living it. Each character is bouna by the force of outwara circumstance to fail to finc plast self-expression ana self-realization. The conflict between personal aesire and external linitations sets up inhibitions anc reoressions in the inaiviaual, which, if they are not satisactorily assimilatea into conscion experience, cause "split personality."

The contrast between iion, the creator, ana 3rown, the poseur, is of especial importince to the understanaing or J'Neill's trentment of the theme of creativeness. In an article written by o'veill to explain this play we find the following interoretation of the cincracter conflict, or "conflict of tre brothers" between 2

Dion and Brown.

\footnotetext{
1. Supra, p. 19

2. Excerptec from the repxint of the article in quinn, op. cit., pp. 192-194.
} 
Dion Anthony -- Dionysus anỏ St. Anthony -- the creative pagan acceptance of life, fighting eterial war with the mesochistic, life-denying spirit of Christianity, as represented by St. Anthony -- the whole struggle resulting in this modern day in mutual exhaustion -- creative joy in life for life's sake frustrated, rendered abortive, distorted by morality...

Brown is the visionless deri-god of our new materialistic myth -- a Success -- builoing is life of exierior things, inwawaly empty, ana resourceless, an uncreative creature or superficial preoráained social arooves, a by-proauct forcea a siāe into slack waters by the deep nain current of life-desire.

From this description we can see the aeep-lying antagonism of the two nen. Brow has always enviea the creative rorce in Anthony -- the thing he himself lacks. Iis entire life is one of attem ted compensation for this lack. ifear the close of the play when he steals Dion's Nephistophelian mask, he thins he is gaining the power to live creatively while actually he is only stealing that creative power turned seli-destructive by complete frustration. Iion, al though posessing the bower to create, could never realize it because of the limitations of reality. Constantly seering the opportunity to realize his creative urge, he tries:

. Iiving ana loving anà having chilären -thinzing one wis creating before one discovered one coul an't. (I, i)

Stunted by family relationships aild ariven by necessity to support his family he arops his painting and turns to architecture in the role of Brown's chief cirattsman. Again he meets defeat because Brown takes all the credit 
for his àesigns, aestroyed the wili to create for the love of creation. Dion explains to Cyoel why he turns to arink for escape from his everyada life.

....(Nr. Brown) hanäs me one matnematically correct barn after another anc I aoctor them up wi tin cute allurements so that fools will desire to buy, sell, breed, sleep, love, hate, curse and pray in them! I do this with devilish cleverness to their entire delignt! Once I areaned of painting winc on the sea and the siriming flignt of cloud shacows over the tops of trees! Now... (II, i)

In discussing the cathearal piens he has ârawn for Brown, he accuses him of stealing his creative life from hin.

I've been tre brains! I've been the aesign! I've designed even his success -- àrunk and laughing at him.. This cathedral is my mesterpiece! It will make Brown the most erinent architect in this tate of God's Country. I put a lot into it -- What was left of my life! It's one vi vid blaspheny fro.. siaewalis to the tios of its spires!... But lr. Brown hes no faith! Ee coulan't uesign a cathearal wi thout it looking like the First supernatural Bank? Ee velieves only in tire imrortality of the moral belly! From now on, Brown will never design anything. We will devote isis lire to reliovating the house of ny Cybel into a home for my liargaret. (II, iii)

Dion goes on to revile Brown for the parasite he is in one of the most bitter passages in all of o'Neill's plays-a passage full of cespair, doubt, and disillusionment. It contains all the raucor, contenpt, and pity which o'veill feels for those who, uncreative in their own right, are so obtuse that they sill the creativeness in others. 
It is immaterial whether the person be male or female -- the sin is the frustration of the creative spixit. Jargaret is as guilty towara Dion as Brown is, although she kills oy possessiveness, not by usurpation. But the end of The Grest God Brown, brought a bout though it is by the thwarting of tre creative spirit, is not entirely without hint of sulvation. Dying in Cybel's ame, Brom bleâs:

$$
\text { I don't want justice. I want love. }
$$

anà Cybel answers:

There is only love. (IV, iii)

Brown aies as bybel speats a reouiem, promising life:

$$
\begin{aligned}
& \text { Alwaye sping cones gatin betring Iife! hlways } \\
& \text { agin! Alwas, alwayo, forever agein! -- } \\
& \text { Soring agsin! -- lite again! -- sumer vala } \\
& \text { fall una deth enc peace aguin! -- but always, } \\
& \text { almas, love ana conception an birtin and pan } \\
& \text { again -- soring bering the intolerable ciralice } \\
& \text { o: Iife again! -- bearing the glorious, blazing } \\
& \text { crown of life again! (IV, iii) }
\end{aligned}
$$

In Lazano Esughea (1926), Lazarus symbolizes the pleksure-ain working itselt out in tems ow full selfrealization and selt-expreseion due seeking after a conolete atriration of life. In tine case of Iazarue, in soite of his repatea proclenation that

$$
\begin{aligned}
& \text { linere is only lifel... There is tetenal ine in } \\
& \text { ana there is the sene terral lige in yos! Lew } \\
& \text { is the face petween!... Death is dend wear is } \\
& \text { wo vore! lhere is only life! ( }, \text { i) }
\end{aligned}
$$


he negates his woris by his own ultimate self-worship ana 1 seli-surficiency, forgetful that se is tre "man in God" wa not the "God in ran." The downtall of his philosophy is caused by the rustrion of the cretive spirit ano the inability to concuer loneliness.

Barly in tae lay, betore his resurrection, comes the contradiction of his statenent that there is no death. His chilären àie, a symbol for the frustration of the creative spirit.

...O late years his Iife has veen one long mispo tune.

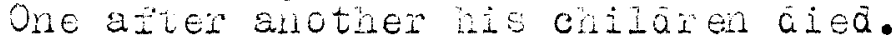
... Trey vere alz gi-ls. Lazarus ha no luck. ...The last wae a boy, the one that aied at birtr. You are forgetting hin. ... Iazarue coula netel loreet. Hot only aia ris son aje but Mirian coulo never bear hia more chilaren. ( $I$, i)

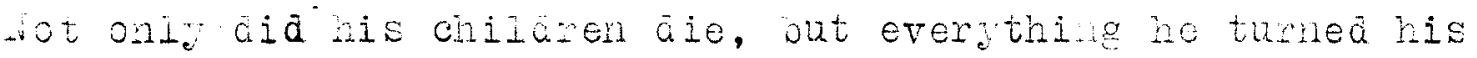

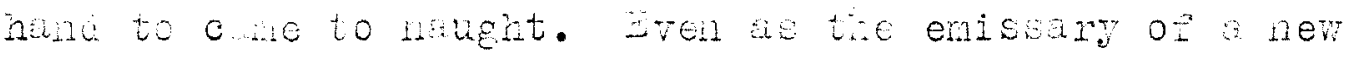
faith in lise he lailed; men responaed brience while he was there to ins ire tren, but as soon as he left, they forgot anc tineir fesrs returined.

1. The idea or eli-Worsin as indicative of libiainal imaturity is, fron the peychonalytic standpoint, a complicated one. Briely, it is aeveloped in the following maner: the chila, aesirous ot status as an indiviual eval to thit of the parent of the vame sex, attenuts to gain his end trrough iàntification with that parent, desiring for himself all the rights ain privileges of that position. Since these are imossiole, he fincs refuge in narcisn in which stete all activities raiate Pron tie self. Thus, the process is from Oedipus (incestuous) desires to narcisn to intraterine existence.

2. See the play, I, $i$, anc IV, $i \dot{i}$ 
The fears of Lazarus followers are basic to their loneliness -- their inability to forget thencelves and to live "with love! -- with prioje! with laughter!" (I, ii) Rather, they live by denying lite.

Lazarus himelif is tomented by the fear of loneliness when he thin's or firiam's aeath. To believe, to be joyous, to live as a son of God is to know a terrible loneliness. Lazarus could never make the comlete break from eurthly things, especially vith is own priàe and self-sufficiency, to become wholly one with his God. It is this pride ina seli-sufficiency which keps Lazarus fron communicating his religious exaltation to his iollowers: and thus concems him to the non-fulfilment of his cretive arive.

Predominanty, niriam is the mother-figure mourning the aetin of her chilaren, the creative aim warped in her as in Jazarus. But she transfers to him her naternal tenàerness anà solicituâe anä, in turn, areaas the loneliness mich his aesth woula nean for her. She is the symbol of woman as wife ana notner of men. Hers is the fste of the wife who cannot grow wit.: her inusbana, who must yiela up physical ana intellectual comonionship anci tane over entirely the role ois the nother. 
In Pompeia's statement that it is her heirt that desires a master there is an echo of rukachin's àream of "a captain of (her) shio on a long voyage in cangerous, enchanted seas." It is the primitive aesire os woman for a man to give neanin and ài cetion to her life. It has reneatedy been O'Neill's contention that the feninine spirit, in its role of crestion and ien wal, if it is not aistorted (in wich case it destroys) is the perfect comlenent to the masculine. But pompeia, à emanaing to be loved as an end in herself, not as a means to fulfillment, cienies her role anà thus negates life.

In answer to the funcianental question in the play, to what cen man I00is to give meaning ana puroose, peace and security, self-realization ana self-fulfillment to this life, oriveili says:

1. "For the vast wajority of men aio women, the sex reletion is the most orofounc of human experiences and the most urgeit of human problems. The instinctive urge towara self-folfilluent, the prinary and unanalyzaile sexual impulse, is accomanied in an awatsened consciousness by the hunger for intimate companionship... ...Those or either sex who pail to acilieve...an intinate relation with sone inaiviunal of the oposite sex are Ielt to have missed tceir destiny. Biologically..they are eccentric to the schene of nature. Psychologically ..they are thenselves aware of a hiatus in their humanity...

"A man shoula heve lea mea that he cannot really be a man unless he has a woman to renew hin, to give hin courage, to restore his faith, ana a wonan siloula Lave learnea tiat she caunot be a woman witnout a man to give airection to the abunarne of her vitality ana to insert àesign into hei life." ilurray anc Young, "Hodern Viarriage," Porum, Jan., 1929, pp. 22-26. 
...There is hope for han! Love is Man's hope -love for his life on earth, a noole love above suspicion atic aistrust!... ara to love Eternity without your fear desiring to possess her! Be brave enough to be possessed! (IV, i)

And yet the play eno s on a false note because Lazarus' pride hes kept him from "being possessed" All his contacts have been fleeting; there has been only temporary success; there is no true affirmetion of life because -- "Ifen forget." The creative arive is back of much of the action in 1

Strange Interluae. San's lack of the inhereit qualities requisite for a man who covia give airection and meaning to rine's life $r$ enders her attempt at renunciation for his sake meaningless. Driven as she is to find some means of satisfaction for her libiainal en exgy which has been aoubly thwarted in the loss of her child and in the failure of her relations with her husband, Nina aetermines to realize her procreative urge with another man. She calculatingly selects itea larrell because she knows that she can trust his scientiric attituae and that he is unadmittedly attracted to her. Darrell agrees to give her a chilü "whose life woula be a Iiving proof that (Sam's) wife loved him" sua wich woula bring her the selfrealization she needed.

\section{Supra, p. 25}


Neill suggests the question of the indiviaual's right to happiness through this situation. Fere are two people (anà a thira is involved), each seeking life in its fullness, each bouna tinrough no faut of his own not to reach his goal unless he particinates in an act condemed by society. There is, hovever, no moral problem for either Ned or ifina, for as Hed says:

There can only be guilt when one deliberately neglects one's manifest auty in life. (IV) Wina's manifest cuty, it seens, is to have a chilo which Will witness her love for fam and which will fulfill her creative role as a woman.

Had O'Neill been coutent to let ilina have her baby anc thereafter perform her auties as wife ana nother mith no other conflicts, he woula have failed to recognize one of tire basic laws of human nature. Stuaies or the sex relationshio between men ana wonon revel thet full love frecuently follows sexual union, but that it selaom cones when the element of sexual aesire is osent. Wina, through her lone, not fully comleted relationshio with sam, cores to have an affection ana materual tencerness for hin, but she never gives hil. a comlete love. In the case of lied, however, complete love rapialy follows their jhysical union. Wina is both thrilled anci alarmea by the reclization of the love between her anc irea. 
..tinen love cane to me. in his me...hapginese! ... I bic it fror hin... I coula geel him ightide Hit. nimelf..auring all those afternoons.pour wonerful afterioons of happiness!

But fina is aestined not to be wole to come into the full realization of the feninine niti: the nesculine esence Decause she cunnot belong entirely to lied as lone es there is Jam. Jivorce from bar is imossible since it woulā cefeat the inst cinefuliy laia plans of re-entercing San's faith in nimself oy the chilo which symolizea nine's Iove for him.

$$
\text { Unable to attach hersel to either one of the male }
$$
elements of release, husband or lover, Wina, after the birtin of her son, seens to Iino through hin release for all her vast store of repressions. Her fuilure in this attempt attests to the neea of womair to find thres-rold fulpillment as wife, wistress anci mother.

\section{1}

In Dynamo, tine love of thy fife for famsar ellow the latter personal freecom in its possession oz him. Eer love is on maci lowen pychologicol level than that of

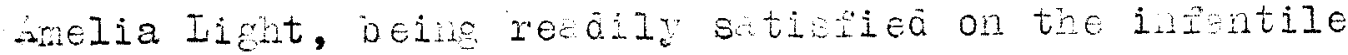
basis of oratifiction of toe pasic libidinel urges. riay Fife, beckuse on nor cillaish Jgo, is a sumbol of earting motherhood realizing itself in its own creation -tine chila gna the nepriness of its nate.

1. suora, p.24: 
Rarusay ife has foun his answer to the quest for life in the suriace represmtetion of the ominotence of electricity and in the sensual satiofaction fourd in his nerital union.

With Reuben, the temency for regression into chilanooc exotionálisn plags a laree nart. Fis atter refusal to accept the res ondoilities of nomel aulthood goes so far as the filling or the feminine siue, represented

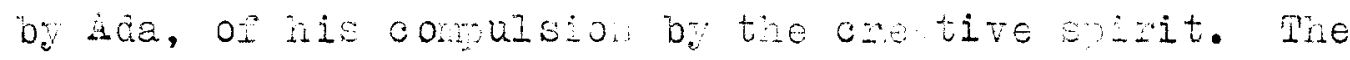
negation of life is inte comlete.

In wournin Becunes Bectre, the cre tive spirit cones out in the aesire of soun of the charecters to live on an islua $i$ the coutr peas where can is as get untouchea by evil.

Brat the sea-cotala kas visitea thie island end his descriptions of the lite thore are Chridine ha Lavinia long to live on the "Beautizlu Isle." Orin who has rea Nelville's Iypee also longs for suci a place. But Lavinia's possessiveness reeps both Brant and Christine from ever achieving their desire by causing their deaths. And ex hatred has so changed orin that by the time they arrive, he can no longer enjoy the life sna forces her to leave just as she reared the achievenent of happiness. Mis is brought out in a reminiscent äialogue between the two after their return: 
Orin: ...We stopoce a ronth. (with resentrul bitterness) But they turnea out to be Vinnie's islanas, hot mine. They only made ne sick and the naked women aisgusted me. I guess I'm too muc of a tanon, after all, to turn into a pagan. But you shoula have seen vinnie wit the men---!

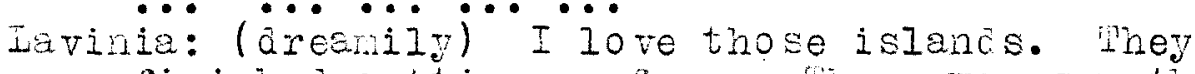
finished setting we free. There was sonetning there mysterious on beautiful - a good spirit - of love - coming out of the lana and the sea. It made ne forget death. There was no hereafter. There was only this worla - the warm earti in the moonligit - the trade wind in the coco palns - the surf on the reef - the fires at night and the arum throbbing in weart the natives anced nakea and innocent - without knowleage oi sin! But what in the vorla! I'm gabing on line a regular chatterbox. You must thin Ir ve becone awfully scatter-braineã!

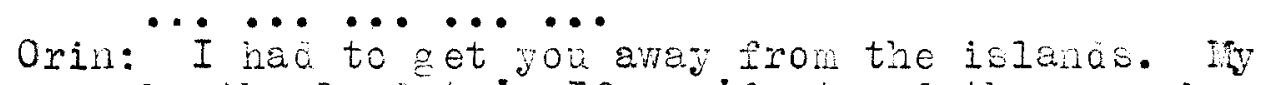
brotherly auty! If you'a stayed there much longer -.. (

$$
\text { (The Hauntea, I, ii) }
$$

Orin's last speech reveils tre antagonism between the two Mhich preventea their making use of the islanā' offering of an oportunity for a fuller life. The sift in

Lavinia's speech, Which sterts ith the interjection, 'But what in the worla!,' inaicates thet the freedom she attainea there was only partial, only a taste as it were. Ier possessivenoss, her brother's antagonism have frustreted their atterot to Iive creatively. The youthful sweethearts of Ah, Wilaerness (1952) have a relationship which, at least in germ, affims rather than denies life. The airl, turiel McConber, is not the embodiment of carnal desires to the boy as Ada is to Reuben 
in Dynamo; she is not the spider-woman who woula kill her mate for her own sustenance. She is a girl who is a friend and coniade as well as a lover, one who will give love and take love, but who will aemana no rore than she can give. She is the swmbol of wonen, vell-rounaed in their physical, mental ana spiritual n tures, who love well because their love is maje up of perfectly balanced elencits of the nother instincts, the wifely attributes of understanding and sympethy and affection, anc the unguaraed ebaloon of willing co-operation in libiainal satisfaction. Richard is a youth, stout of heart ena woring into surety of purpose, who can face life without sinrinking because he is an entity i: hinself, yell djuted already and capable of further adjustuent to tre a emanas that vill be made on him. The union of these two, founded as it is in the give-ana-take of gooả fellowship, unity of purnose, and mutual affection ana consideration, promises to be one of calm assurance in shouldering the $x$ sponsibilities or the creative soirit, the sorce of which they are to realize. Whe main theme of Daye Without end is the affimation OA Iife which comes as tho result of the indiviaual's faith in love. In this play, love is deoicted in many forms. Primarily there is the love ot God for man and of man for God. The love between a man ana a woman and the conossionate love of one hum being for another which tather Baira

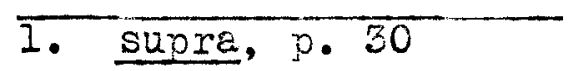


has for John are the two most imort nt types which fuse into the higher love. The love of one human being for anotier asymptotically aproaches aivine love, but is never iàntified with it, becuse of human limitations. As Fatier Baird says:

I'm not douting your love for her nor hers for you... I an thinking that such love needs the hope snd oromise of eternity to fulfill itself--above all, to feel itself secure. Beyona the love for each other shouia be the love of Goà, in Whose Love yours may fina tine triumph over aeath.

(I)

Only as human love aproaches the infinite love or God as the creator ana keeper of life can it becone fully setisfactory anà secure.

Even in this play which is the strongest testinony for life affirmed we heve a in trace of refuge in regression -- a longing for the irresponsible state of complete protection that is the mother's wonb. One ias tance of this comes early in the play in John's failure to proceed on to tine ena of his novel. Fe hesitates ana tries to retum to the emotional security of parental love. The other important stitenent of it is seen in Jonn's fesr of Isa's cieath.

...oeth is what the dead know, the werm, dark womb of irotringuess -- the Irean in which you and IIsa may sleep as one forever, beyono iesr of separation.

( IV, i) 
However, John and Elsa are strong anā nature enough to carry on anc win tinough by facing life's realities with courage ano faith. Days 能hout End is a play of sylendia effirmation, "of a man's problems in the full surge of real lise."

The need for the Iulfillmest of the creatre epirit is aemonstrated in Before Breazfat, Beyonà tine 10rizon, Gold, The Eairy Ape, All God's Uniliun Got Wings, lhe Grest God Brown, Strange Interliāe, Dynano, anc lourning Becomes Electra. The tragic outcome or these plays is puilt, as we have seen, u on the insbility of the cheracters to rina an outlet for their creetive urges. While it nay seen an empasis on the ovvious, these chracters neet tregedy either sucienly or nore protrectedi in a process os slow peychical poisoning beckue they refuse to accent the realities of humen exiatence ana make lives for thomselves that Iurther reter then aestroy the oseibilit of growth. Pewaps the most striking instance is lla, of thI Goa's Chiliun Got lings, wo, after long refusing to athe the Dest of her narriage with the negro, Jin, and after seltishly aenying him ach o: lise, finally loses her reason. Another is Yank of the Har spe who, teeling that he is neitrer nan nor animal, goes in a blina frengy 0 ? frustretion to die in the arme of the ane who seens nore his kinà than wan coes. 
But in aảition to this negative aenonstration of what hapena when the creuive spirit goes unilfilled, O'Neill has pointea out mays of fulfilling tiese urges. Wuisachin in Marco Millions triumphover deatr because or the icel depth sia unselitishnes of her love. Old Jusin of lhe Fountain, even as he aies, receens a life ot.erwise largely sterile by his final cealization of the all-impotance of love in lite. Similar in imort are Ihe Straw, Ania Oristie. Helded, An, Wilaeriese, and Davs Without End.

Mixed in implication are Ine Pirst Man, Desire Under tie Elns, and dazerus Lauged. In tine first two, folfillnont of the crestive spirit is belated and only partial. The crestor dies in giving birth to his creation anü Eben faces a aeath which though guilty affirus life in its sacrifice of his Ego to his love. In the third, Iazarus is passionately aware of tine aeeü to love life, to be possessed by it but because of his priae of seli-sufficiency, he refuses to give hinself up to its possession. The consciousnes, of his insight turns uon hin and he rails to become a creator.

Thus we have seen that orifeill is àeenly convincea of the need of the creative enimit for fulfilment. ina that he believes that an ecceting lore of life all a seltsacrificing love between man and moman afforà the best means to this integrally importent fulfillnent. 
Chápter Three

The Problen or Ifan's Salvation 
'The problem of man's salvetion, of man's adjustrent to his environnent, is of the most pressing and constant ones with wich we are confronted. $\tan ^{\prime}$ s achievement of a satisfactory way of life is the chief, though often overlookea, gosl of philosophy. wile the problen may seem solely etinical, its involvenent or the psychical man's relationship to other men and wonen, to the esthetic, to the supernatural, or better, the superhuman - extends into all reaches of knowleoge. The importance of tisis problem to tine individual and to all humanity is clear; \& fact which rencers obvious o'ieill's interest in it.

There are for him, three waJs in which ajustment may be attained. These are: through moral re-evaluation, through faith, and through love."

By noral re-evaluation is neait the selection of those behavior patterns which briug satislying results and the aiscaraing of those, the end-products of waich are negating rather then fulfilling. This woulà incluae the throwing-out of customary, traditionel was of acting Wich no longer serve their ourpose. Faith, to O'Neill, is the trust of an indiviaual in a power outside and more than himself, ranging from the vague feeling of something beyond to the definite declaration of faith in a forgiving and loving God. 
Iove signifies both the funamental attraction and relationship between the sexes ana that symoathetic understanding and tolerant affection which an indiviaual nust feel for those around him in orāer to live life fully. This love is larger than the inaiviaual, it incluaes all humanity in its emorace.

Faith in sometning beyona man anc beyona life is 1 accented in Beyona the Eorizon. The belief has its basis in the iajea that sacrifice is always somehow recompensed. the areamer, Robert, exoressed this faith even as he dies. Se says:

(in a vice which is sudaenly ringing with the happiness of hopel You nustn't feel sorry for me. Don't you see I'm hapy at last---free--- Iree!--freea from the farm---free to wander on and on--eternally! (He raises hinseli on his elbow, his face radiant, ana points to the horizon) Iook! Isn't it beautiful peyona the hills? I can hear the old voices calling ne to come--- (Exultantly) And this time I'm going! It's a rree beginning-.the start of my voyage! I've won to my trip---the right of release---bejouc tire horizon! oh, you ought to be glad---glaa---for my seire! (III, ii)

Ee adas the aúvice to his brother, snarew:

Ruth has suffereà---remember, Anajy---only through sacrifice---the secret beyond there--(III, ii)

Thus Robert, the à reamer, a i es exultantly in his comolete faith that surely there must be something beyona there to make up for the life thet hac been so wasted by the

1. supra, p. 2 and p. 85 
demanding possessiveness of hiswife, Rutin. Fe also believes that the two he leaves behind will achieve happiness for tremselves now that he is gone. But unfortunately this belief is not shered by them; Anarew is bitter, Ruth hopeless. In the end, Robert, though dead, has, because of his àreamer's faith, come closest to happiness.

In Ihe Straw, tine entire action noves to the climax In which love is shown to be the way by wich life may be made livable for doth persons affected. This clinax is the character chenge in stephen iurrey brought about by his sudaen reglizetion thet he ooes love zileen, even as he tells her he does. This love changes Stephen from a selí-sufficient, self́-lovine, and largely self-centered man to one who suddenly discovers that there is something else in the world; he weeps:

(Raising ils face... alight with a passionate awakening -- a revelation, he cries) oh, I do love you, Eileen! I do! I love you, love you!

The effect of the earlier relationsip, only companionale, upon the two promises thet this discovery of Stephen's will enable them to work out a saticfactory life together.

In Anna Christie, What sacrifices his price, effronted by knowledge of Anna's osst, to his love for her. His pride was salved to some extent by her assurance that he was the

1. supra, p. 5 ana p. 50

2. supra, p. 6 and $\mathrm{p} .57$ 
only man she had ever loved; but even so, he forgave her her earlier transgression agajust the double standard alid re-established their relationship. They planned a future, each in possession of the other, put both belonging to the sea -- the uncertain fate of man. And naving this two-fold sense of belonging, their life shoulä be hanpy, even though Anna can ilever regain a part of her priae and self-respect anä, trus, cannot belone completely to Mcit. Foundea on sacrifice and on honesty, their love, given its ntural element - the sea, should veathe- and storns that might cone its way.

In Ine Bountain, Jual Ponce ae Leon, the aged seeker after etemal Jouth, finos as he is aying that $10 \mathrm{ve}$ is the only answer for his quest. Iis a esire ror etemal youth is notivated in the first plece by his chagrinea consciousness of wnat he had missed as a jouth in refusine laria's 10ve. Ve longs to remeoy his oversight with beatriz, varia's daughter, out in the eno he discovers that it is too lete and all he can äo is give his blessing to tre love petween Beatriz and nis nephew. nis last act to sone extent saves hie life fron comlete wate. Juan's indoility to achieve fulfilment, to be euricient unto nineeli without love ie a concrete demonstration of love's imortance.

\section{1. $\quad$ sara, $2 \cdot 42$}


Por our parooes, the imortent treme it vereo vilions is love. Only on the surface is it a satirical conecy. Jenesth there Iiss a trakic seening efter a peace-giving besuty which e n tronsforn the cruae, restless, deadening, temible elchents of iffe into sonetning nore. orieill does not tell us mat this "sometnine nore" is; he indicates that it is necesser oy snowine thet whet we hye is not enough to give the ultimate peace sua sutisfution of a completely integuted personality

Eurachin, the symbol of tenderuess and besty in love which can attain salration, stencs in contrest to Iarco, the nasculine soirit äistortea and soiritually awarfeà by its suonission to greed. Lurechin is a wonda Wo sees encomossing love a the aim and end of life. Love is the sorce of all that is gooc; it is unseltish, humble, understunaing, sud forgiving. It is the soul's reaching out for completion on three levels - nental, Jivsical, anā siritual. Were can be no real love mithout elentits from each of these three cutegories. In Kursenia's love Iies the 0.17. hone for tarco's soul. As Cu-Yin says:

-.. I reasoned, who knows but some cy this larco nay see into her eyes aid his soul may be Dorn ..- 
No soul is born in tarco ana his grossness is comlete. When she rinally realizes that, zukachin accuses him.

There is no soul even in your love, which is no better theis a mating of swine. (II, iii)

Mio crassuess zills her oirit; but whe still loves love. Tukachin's woras in the prologue which opens the play give us tre full imort of hes function as the symol of love:

Say this, I Ioved and àied. Low I an Love, and live. Anc Iiville, have forgotten. And Loving, can foreive.

Whe trone of tho con Ie entation of the maculine

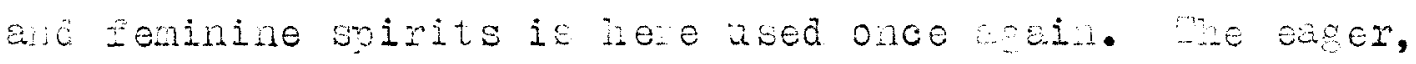
nomole, tender, delf-sacificing love of Fukachin as representetive of feminine lovest large is destined to be ever uns tistied oy tine helf-giving, half-withnolóng of the nasculine epirit. It is imperativo for the woma to feel that she delongs to her love-object as well as to know thet she possesses it. Fukachin realizes weither. Ia her love been no larger, hers woulo have been the tragic end, not harco's. But her love, as iảekl love, surpasses the pochophysical limitations in tre unerstanảng which comes in spiritual beauty.

In opposition, we have the love of Jonata, stout anà midule-ageâ, her face unlined anō prett in a bovine, good-natured way." Her love will be confortable jut not upliftisg and stinulating to the soul. Sucin a love as 
Donata's, or liarco's, eventually blights the tring it loves or zills it, smothering it in its ow deadening apatiny.

Ine prostitute which o'veilI introauces into the civilization of each country the polos visit on their way to Cathay is a symbol oi the combinea elewents of man's eartnly aesires ana his life-long search for motherhood 1

in iature. Sine is the exbodinent of one type oft terinine love, Kuirachin of chother, and jonata of the thira. The three types of feninine love which o'veill so frequently delineates must de combined into one to make for a full enotional, sensual, anò intellectual relationship between a man anc a moman. Ireua says that no nerriage "is firmy assured until the woman has succeeaed in making her husbenà (and lover) into her chila anà in acting tise part of a nother towaràs hin." o'iveill has clearly stated this ides in the chorus of the women attendants when wuachin is to meet her new lord, Grazan, Ehan of Persia. Whey chant:

\footnotetext{
1. This perpetukl seeing for nuternal protection is explainable in terns of failure to achieve satisfactory àsolacenent ana transference wich free the ināiviaual from enotional àepencence on the notnerimego.

2. Freuá, op. cit., p.. 132-183.
} 
The lover comes

Who becones a husband,

Who becomes a son,

Who becones a father - -

In tis contemplation Iives the woman.

(II, iii)

Loneliness is another spect of the problem met in this play. Life is lonely when the inaiviajal is unable to feel hinelf as belonging to or possessed by sone ooject-choice, whether animate or inanimate, to which he can cling and through which he can expend his libidinal or suplinatea energies. Tublai Zhan says to Kunachin:

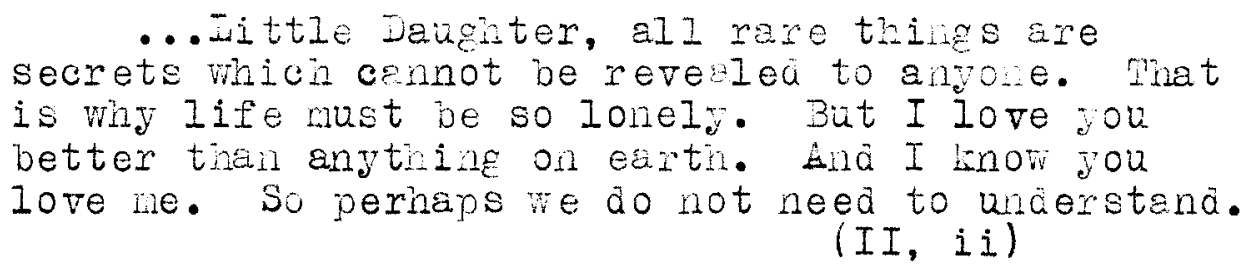

All-embracing love is the only thing which can remove the feeling of loneliness. Tne complete fusion of the elenents of love is so rare that it is a aifficult goal for an incivioual to attain. Tuachin is asking fox this when she seys she desires

a captain of my ship ou a long voyage in àangerous, encinanted seas. (II, ii) Inece is no one who con fulfill her desire, so she must travel on alone. Hhus the characters in Marco Millions, conceived as they sre as variations o. the thene of $10 \mathrm{ve}$, show, each in his own way, that there must be "sonething more" than that which man has already attained before he 
can find the rullest possible meaning in life. In other woràs, to keep from a aeatin in life, man must grow ana continue to grow.

Itan's desire to find me $\frac{1}{1}$ in life is the primary problem in The Great God Brown. O'Neill has used Dion's frantic serrch for pece and contentment in the love of woman as the unconscious airection of his deeper quest for inner harwony which will bring him unity with his God. Dion's chaotic actions are efforts to realize his aeeplying aesire to fino sonething to give meining to his life. Fe thought he hac found it in Cargaret's love. Ee tried agein to find it in his painting sna srchitecture, but they turned into blasphemies. The closest he ever came to meaning in life is in his aoctrine of "blessed are the meel and the poor in spirit." However, in the continuetion of Dion's cheracter in the person of Brown, O'Neill does give us a final note of triump when Brown aies, seying:

...I Know! I have found Hin! I hear Jim speak! 'Blessea are they that weep, for they shall laugh!' only he thit has wept can laugh! The laughter of He ven sows eartin with a rain of tears, and out of Earth's transfigured birth-oain the laghter of tian returns to bless ana play again in innumerable dancing gales of flame upon the knees of Goa?

1. Supra, p. 19 and p. 50 . 
As he has so often done before, ONeill symbolizes $\operatorname{Tan}^{\prime} \mathrm{s}$ quest for the meaning of life in a power outsiae hirself in terms of a force wich is uncerstanable to him -- that of love with its elements of lioiad, friendy affection, anci symethetic uncierstanding. As we have pointed out in another context, the fundanental question in the pley, Lazarus Laughed, is whet can man look to as tre souce or mening and purnose, peace and security, seli-reclization ana self-fulfillnent in this life. In answer, olvill, in the person of Iazarue, proclains thet

$$
\begin{aligned}
& \text {...there is hope for Man! Love is Man's hone -- } \\
& \text { love for his life ol exth, a noble lo e above sus- } \\
& \text { bicion ana aistrust... äure to love Etermity without } \\
& \text { your fear desirine to possess her! Be brave enougin to }
\end{aligned}
$$

We are not to unerstana from Lazarus' failuze tint his is a useless fomula; it is not tie fomula thet is at fault but Lazarus who is too wear to put it into pretice. In spite or his insignt, he cannot lorget nimelz ana his pricie of self-suficiency lone enough to be really at one with life. Although hnowing that life wust be accepted, he still refuses it. Here o' Jeill hes once agein emphasized with his 'Iove is Jan's hope' thet love is a most valia answer to tho cuestion ot life.

\section{1. supra, 5.50}


1

In Dynamo, this speech of reuben's

I wht to face things. I won't de satisried now until I've found tae truth about everything. (II, ii)

gives us the motivation ar his actions anc tyos the play as one that is concerned et leet in pait isith the

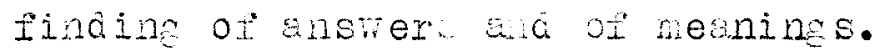

As a youth, geuben lived in fear of his father, the familiar character of the stern $f$ ther-god of zuritan treaition, and in the protecting love of his nother. Fis own beliefs are e conooite of theirs, "an accentance of feir anc an uncuestioning aith in maternal protection."

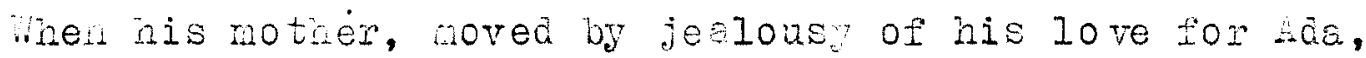
betray him to his futier, he loses all faith an finas it impera tive to find his omn answers. The renainaer of the play is hede up of reuben's quest after the ridale of lite, a thing which no never tios even in hie sinal attemptea union of himselp suc tire great eartinother in nis suiciae on the annemo.

Reuber's choice of electricity, of the avnano ss an objective Goa-smbol is ensily uncerstood; he knoms the ufethomable and neterious power of electricit gna tine souna of the annano is alnost always in his ears. Iis fixation upon his mother, the eifects of which we heve outlined in sone àtail in an exrier chapter, is the decisive factor in his revaring tie ajnano as a nother-

\section{I. suora, p. 24 and p. 59 .}


goàdess. Anc hie obsessec longing to see his dead mother, to be forgiven by her, bring him in tre end to suiciae. In the ena., we are apt to feel that a dynamo is haraly powerful anc emotional enough as a smibol to satisfy main's àsire for a nore profouna raport with life. But we cannot seriousl. believe that o'ileill neant to offer it as such a sydol. That we nave here is Reuben's failure to fina a life-affiming answer; a failure that was caused by his umilinguess to ajust to life on any but cinidline, or rather, fetus-iice terns. Wnt orieill is pointing out nere is that we neea to face lice as aculte, resaj to Pace its defeits, its uncertainties ill our own persons; acting tius, it nay de reguirea of us to go over the precipice, into the unknown but alwaye shoula we be courageous, never, in auy event, should we whimper anci cower back to seek wistiuly the cosy, irresionsible and uncemanding protection of the romb. If we act as adults, we nave a chance to sajust, to fina happiness, but cowering back, failing to meet lile on its own terms can only mean a aeetr-in-lite, a feilure lize that o emonstrated by Feuben's suicicie.

\footnotetext{
1. We feel, as Skinier saje, thet "the hunger wno thirst of $0^{\prime}$ Ireill for sone sort of spiritual resolution of the wighty conflict of the soul has a signilicance which far outweighs the cruảe zna orten repellent quality of the symols used in aescrioing his cuest." Skinner, op. cit., p. 219.
} 
Daye Hithout End is o'Neill's clearest and most concrete representution of faith in a forgiving ana loving God as a solution for the problems of life.

The action of the play reveals the role faith plays as a solution. John is married to Elsa, a wowan to whom ficelity in narriage is o prime imortance. She left her first husbana as soon as she knew of his inficelity. She married John because she thought she had founo in him a man to whom marrigge is a sacrament as it is to her. Their marriage is moàel until John, criven by fear of his happiness, tries to make himself incependent of their love Dy killing it through äbasement. Wher Fisa, dy means of a novel plot and the story tola by her Irienä, Jucy Hilimen, of her own adultery, learns that John has been unfaithul to her, she wills to aie, deing alresay ill with inguenza. John is nanic-stricken at the thought of her death, knowing full well that it aens that he will be throw dack onto the long, wery road of doubt and self-torture. Ee beseeches her forgiveness. Le finally goes to a church and there, at the root of the cross, prays thet Else will live aná forgive him ana love him again. He leves the church as a man whose salvation has been wrought through faith anā love. In the play, John's surrenäer to the love of the Crucifiea Christ oriags avout the aeath of Ioving, the secona stage cheracter that represento his bitter ana 
aisillusionea self and with the death of Loving, he becomes a unified, integrated personality, John Ioving. The need for faith is illustrated in Father Baird's speech :

$$
\begin{aligned}
& \text { I'n not a oubting your love for her nor hers for } \\
& \text { you... I an thinking that such love needs the hope } \\
& \text { aid promise of eternity to fulfill itseli---anove } \\
& \text { all, to feel itsell secure. Beyonc the love cor } \\
& \text { each other shoula be the love of God, in Whose Iove } \\
& \text { yours may ina the triumpin over death. (I) }
\end{aligned}
$$

Thus clearly in Daye ithout Qua has o'veill emphasized faith in a power weyona and above man as perhans the most all-inclusive instrument with wich to àscover a fulfilling sufficiency of meaning in life.

Of the three vays ou salvation inaicatea by o'Neill, moral re-evaluation is given the least documentation. Anne Christie is the only play thit is concemed with it; and tat's refusal to abice by the tenete of the doule stanara is as much or more causea by love than by any sense of the deficiencies ox need for $r$ evision of this moral code.

The two renaining ways, love ana faith, are o ten intertwined aná represented as mutually interdepenàent. Days lithout End, for example, points out tht laith in a loving Goä is a wost lecessary reinforcenent of the love between han an woman anà in Iazarus Iaugned Iaitin means man's confidence that love of life will bring its own reward. 
Faith is of seconary importance to love in Ifrco Millions, The Straw ano The Fountain, lays that place their main depencience upon love. Fukachin's triumph over deati, the chenge wrought in stephen lurray, a:ta Juan's insufficiency wi thout love all aemonstrate love's importance anà nesing fulness.

Phe Great God Brown and Dynamo represent unsuccessful quests azter tine meaning or̈ life. In the first, the failure ts relieved by Brow's dying statement o vivifying power of suffering, especially as it contrats to happiness ana thus brings man to rejoice in lize and the goodness of Goa. In the seconá, Reuben's suiciue, jrought about oy his nother-rixation, denotes complete failure. Fere, as we have pointea out, orreill is saying that we must face life as aults if we sre to win through to adjustment ana integration of personality; ana thet regression to chilahoo is a li-aenying escare thet cannot encomase nything but our ruin.

As we have seen, for o' Neill faith anc love are but opposite sides of the same coin, ecch viald enough oy itself but finding its highest meaning in its realizea conjunction with the other. Foral re-evaluation is imontent only Where it nust be brought into play as a founcation for faitir and love. 
We can say with certinty that O'Neill would answer the question, How can life be justified? How can it be made livele? with the phrase, throuch faith anci love. Faith, that is, either in a power bey ond man or in the essential goodines of Iife; anci by love meaning not only the fundementel relationship jetween nan ana wornan but a tolerant anc accepting attituảe towarả all humanity. 
Chapter Pour

Conclusions 
Conclusions

The purpose of this paper was to determine, if posible, what Eugene olveiz's jilosophy was from studying the ways sex moblens were used in his plays. phe questions raisea were:

1) Are ses probens usca as a source of rielodichatic action?

2) Lre tirey used as a me ns of a epioting cheracter and torwicine crevatic ection?

5) Are trey useà as a new of expecine miloEopice i ices?

The walysis of the lays uncer the gore remises

gives us the following conclusione:

1) Odeliz's use or sex problers is tar from being werel welocirenatic; such problene are basic to the expression or his philosoph

2) Towara the expression of his philosopin, he has selectea, conscionely or unconsciously, the fundenental experiences of huan veins explainable as the elan vitel in terme oz the lioido as harooring the situations wich elicit the nost direct res onse. Ge uses livicinal cethoris as the basis or comon uncerstenäine compoundea

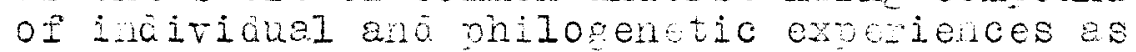
the nucleus from wich he dran tre motivation for charecter-action an as the foundstjon for tine action-situatione mich give the best oportunity or the presentetion of his icess.

e) $V^{\prime}$ Neili's nhilosophe is humalterisn and pragntic becsuse os his dee sympthy for the incivicual and because of his rejection of Wye or action which prove thenselves worthlese: "sctions or attituaes are rejectea when tin entail frustration and hegation of life, anc some other action or attitua is cought wich nolcs greater promise of workebility. 
4) The aefinition and clarity rith mich we have arawn out the iaeas in o'veizl's nlays by uaing the tents of lioiainal cathexis should go far to cenonstre te the error of those many critics who tere the position that the conteit of tre plop is as a "ask rorest," pilled with meanings thet are jot to de eluciacted or stated.

Inswuci as plye wituen from nerely sensational notives are hardy buráenea with iceas, and inasuch as charcter and ation aie tre dranatist's only redns of

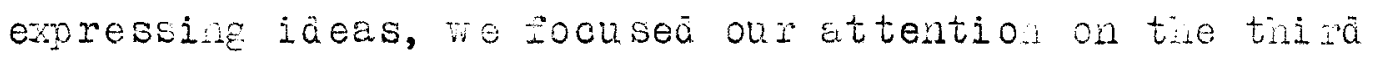

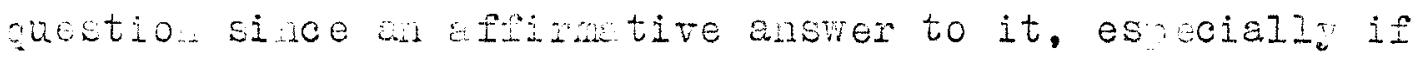
the ideas enpossed were of ang notundit, woulo controvert

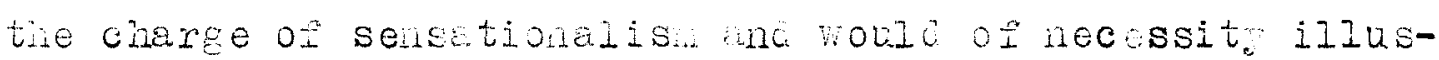
trate the reletionship between sez roblens snd cheructer and action.

To arrive at an an swer to this thira question, we analyzea O'Neill's use of the following apects of the problem of libianal cathais: the problen of the possessive spirit ith its cowrelative pioblem of sez antegonism, the problen oi the creative soirit, the poblen of man's psychic salvation, that is; a satisfectory bajustrint and integration of yersonality.

In the first chapter, aevoted to the problem of the possessive spirit, we point out the various manifestations of this problem. Of first importance vas feminine possessiveness and its counterpert, man's aesire to be possessed as by a mother. Ihis incluāea the antagonisir or the serses,

I. Cf. the reference to Ealfora Iuccock, supra, p. il. 
especially as thet antagonism was motivated by the conflict between the shothering sujjective poseesiveness of the moman and the more or lese objective poseessiveness of the male. Secona came the osychic possession of persons by an exterior force -- as, for example, the sea in Ana Christie. Thira was the arrive to the possession of meterial thins or greed, which for the psychoanalyst has its basis in libidinal cetiexis.

After analyzing the plays concernea with this problem,

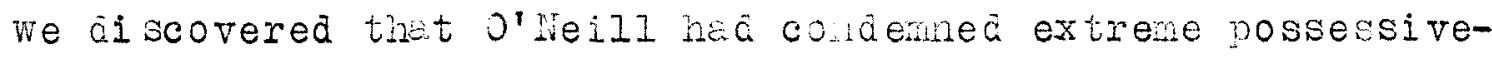
ness by denonstrating the $t$ its conseruences were in the majority of instances trâgic.

Only four or the plays treated were not tregic in outcone; only two of them were concerned with greed, the externalized form of extrene possessiveness; only one with the possession of persons by an exterior force.

Implicit in this concemation of possessiveness Was the suggestion that self-sacrifice offered a nuch better means to accomplishing an adjustuent between inciviajual ana inàiviáual ane between the inàviăual ano his environment.

Whe problem of the creative sririt was the subject of the secona chapter. It was aefined as consisting of those conflicts, frustrations anc inhibitions encounterea in such sublimative channels of the libidinal cathexis as artistic 
endedvor, chil abeering anà rearing. Another nanifestation, less obviously sexual, was the desire to have an iaentification with either a group or a natural force.

The effect of the death of a chilà, whether naturelly or artificially causeã, was citea as an example of what repression of these second ry channels weant to the inaividual thus sfflicted.

Nine of the plays consiaered in this chapter embaied a negative aemonstration of what hapens when the creative spirit goes unfulfilled. The characters of these plays met tragedy as a result of their inebility to finä an outlet for their creative urges. Whis tragedy was either catsotrophic or gradual; in either case, their refusal to accept the realities of human existence aid make lives for thenselves thet furthered rather than prevented growth was responsiole.

Seven plays illustreteä, usually by imlication, what the revara wes for fucing the provlen of life and aealing with it courageously, crestively.

Three were nixed in neaning -- two of then, while tragic, were relievea by a partial success in realizing the creative impulse. The thiza wes perha s the nost tragic play in the whole chapter, since its chi figure had a zeen percetion of the need of affiming, of accepting life but was kept by his oride of self-sufficiency 
from giving himself up to life; the consciousnes of his insignt turneả upon hin anā he faileả to become a creator. The content oi tinese plays clearly originated in o'ileill's consciousness of the need of the creative spirit for fulfilment. Also inaicatea was his delief that an accepting love of life ana a self-sacrificing love between man and woman were fundamental to this integrally important fulfiliment.

The problem of how nant hay save inimelf was taken up in the tinira chapter. It was emphasized that this problem was continualy met in life and that finding a solution for it was philosophy's chief goal. It was considered to extend beyona the etrical into all reaches of knowledge. The frequency and human imortance of the problem was given as the basis for O'Neill's interest in it.

He had inaicated three ways by which adjustnent might be made. These were through roral re-evaluation, through faith anci through love.

Moral re-evaluation meant maing those behavior patterns or ways of thining inaitual that had consumatory conseouences and the aiscarding of those the results of wich aenied rather than affimea life. In this throwing-out woul a be incluaea those traditional ana customery way which were no longer efficacious. 
Paith was the truct of the inaiviaual in a power outsiàe and more than himself, ranging from the vague feeling $0 \%$ something beyona to the aefinite aeclaration of faitin in a forgiving anc loving Goà.

Iove signifiea both the funciamental relationshio between the sexes ana that symathetic una erstanaing ana tolerant affection which sinciviaual must feel for those arouna him if he is to live life fully.

Iforal re-eveluation was docunentea in only one of the plays analyzed in this chapter. Ana even here, the man's aecision not to abiae by the tenets of the double stanàa was nuch nore due to his lowe then to any sease of the aeficiencies or need for revision of this moral coäe.

Paith was oreaninat in one play, in which the aeati of one chericter was assuegeà by his aeep conidance in sowething beyoud that woula recomense hin for all the sacrifices he naae in lite.

In tinree plays love was emhasized. The effect its presence or lack had uoon tine cheracters involved wa a clear demonstration of its importance. Love and foitin were renresented as intertwineà anà mutually interóepenāent in two plays. In one it was pointeả out that faith in a forgiving ana lo ving Gó neightens and dignizies the love between man and wona: 
and in the other, fuln wes man's trust thet love of Iife woula bring its own revara.

Lwo plays involved unsircesstul attenots to oiscover the meanin of life. In one, tho failure res only partial Decuase the man discoverea tire role of sulfering as a contret to nepiness and thus as a means of oninging man to rejoice li lise and the soounese of god. In the otier,

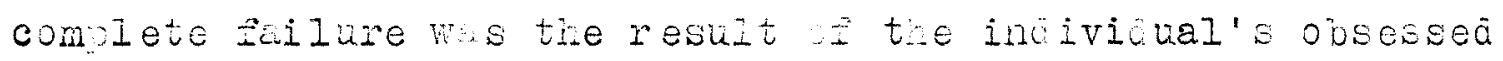
desine to ceturn to an intrautenine existence. Fere orreill is sajing that we mus meet life as aults and test rotontion of childnooù aependence is a denial of lise, a nincrence to the cevelomest on tine inivicual.

Tor cheill, faith anc love are oposite sices of the seme coin, eccir velia enougi by itsela but finding its highest meandag in its realized conjunction with the other. Oleurly through feiti wh love woula be o'meill's answer to the quetion Jow on life be ustified, now can it be made liveble?

It seems only too obvious thet a witer mose purnose was ciniefly nelocranetic woula be irc pable ol expressing suci an answer to the besic question of man's existence. Whe content wo nave aiscoveria in the iajo is, lizerise, mon bove the level of the sensational and of such a 
quality that it cinnot be au. Iicated in shocking or obscene Iitenture, eithe arantic or of other kincs. As andobitolel werrint for our concetion of O'Veill's nigh mission as a cranetiet, we neve his 1

own sisteritent:

Zost mocem playe are concerned with

tive relation betweeir man and man; I an oniy concerned witn the relation detween Goä ana man.

It shoula be renemberea that grieill's conception or Goa, especibly in the leter log, is the the Godresa serves as a symol for atidrab ad accepting attitudes

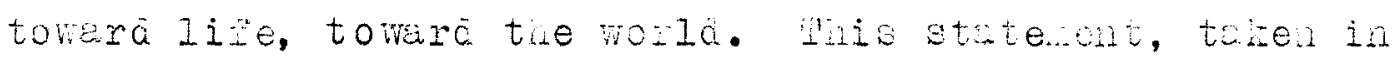
conunction win the contert of the play, revens thet greil is a nouem noralist.

$\mathrm{Ee}$ is moäern in the the does not conaem way of acting as evil in thene elves; he only cemonstrates tile tallacy of such way by showng thejp results. Ge is morelistic in his interest in äscovering lew sic better ways of living; in developing pateris of bengvior that enrich and fee tre incivicual ratuer than cestroy and imprison him; in aiscaräing, in custing out those ways wich are ineficacious.

1. Zrutch, Joseph Wooá, Introauction to mine P1se oy ELgene O'ieill, p. xvil. 
All in all, we nay concider thet o'feill is at least endevoring to perform the highest runction of the artist; he is trying to beat new peths, to aiscover new neaning in iffe, to bring new imnealacies, new consumations within the reach of men. Anà we woula say, aster our stua of his works from the standpoint of libidinal cathexis, thit his use ol norchonalytic categoriee has heloed rether than hinderea him in his attempt to achieve nom eno unique incigents into the problem of life. 
Bibliograpiny 


\begin{tabular}{|c|c|c|}
\hline $\begin{array}{l}\text { Authorship } \\
\text { Date }\end{array}$ & Title & $\begin{array}{l}\text { Book litie } \\
\text { sud Publisher }\end{array}$ \\
\hline $\begin{array}{l}1915 \\
1915 \\
1910 \\
1914 \\
191 \leq\end{array}$ & $\begin{array}{l}\text { Thirst } \\
\text { The Weo } \\
\text { The Fog } \\
\text { Warings } \\
\text { Recklessese }\end{array}$ & $\begin{array}{l}\frac{\text { Thirst }}{\text { Ant }} \frac{\text { Other }}{\text { One }} \\
\frac{\text { Plas }}{\text { Bon, Gonran Press, }} \\
\text { 1914 }\end{array}$ \\
\hline 1914 & Bouna East Zor Caraiff & 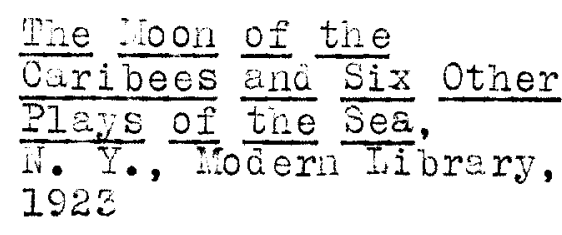 \\
\hline 1916 & Before Breaifast & 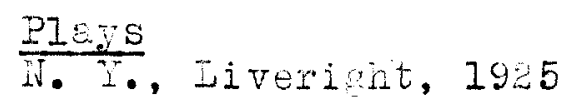 \\
\hline 1916 & 'IIe & 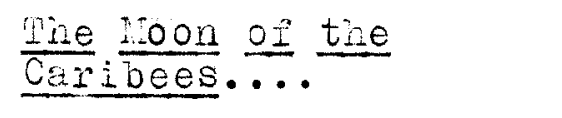 \\
\hline 1917 & In the Zone & The ioon... \\
\hline 1916 & The tong Voyage Fone & The ioon... \\
\hline 1910 & Woon of the Caribees & The Moon... \\
\hline 1916 & Whe Pirst Iran & $\begin{array}{l}\text { Plays } \\
\text { Inter 3oni } 8 \\
\text { Iiveright, } 1922\end{array}$ \\
\hline 1918 & Beyond tine Horizon & 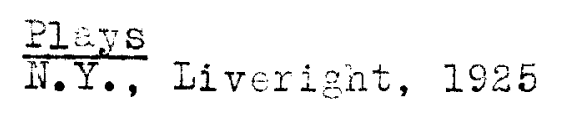 \\
\hline 1918 & The Dremy Zià & 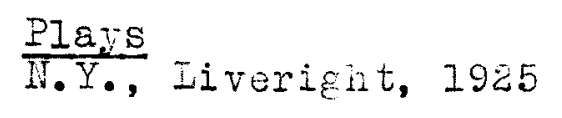 \\
\hline 1918 & The Straw & 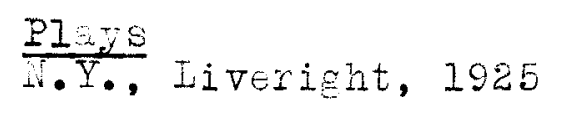 \\
\hline 1918 & The Rope & $\frac{\text { The }}{\text { Carioon }}$ ibees. of the \\
\hline 1918 & Where the Cross is Macie & Pre Ioon... \\
\hline
\end{tabular}




\begin{tabular}{|c|c|c|}
\hline 1920 & Gold & $\begin{array}{l}\text { Plays } \\
\text { N.Y., Wiläerness Road } \\
\text { Ed., 19a5 }\end{array}$ \\
\hline 1920 & Anne Christie & 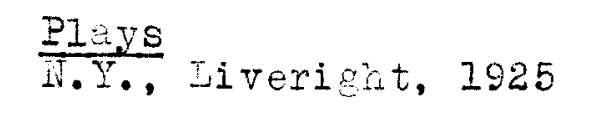 \\
\hline 1920 & Emperor Jones & $\begin{array}{l}\frac{\text { Hine }}{\text { Wlays }} \\
\text { ISE2 }\end{array}$ \\
\hline 1920 & Dist'rent & 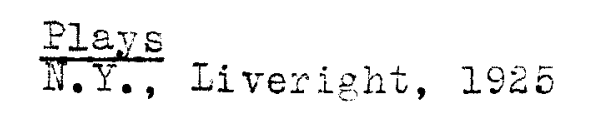 \\
\hline 1921 & The gountain & 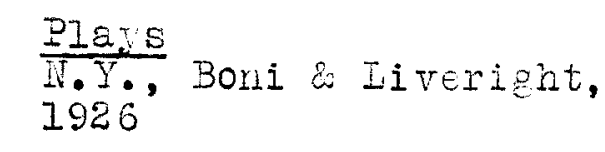 \\
\hline 1921 & The Tairy Ape & 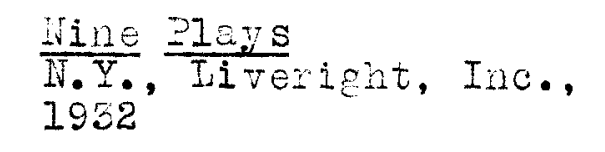 \\
\hline $1922-2 z$ & Welò ed & $\frac{\text { Plays }}{1925}$ B.T B ilveright, \\
\hline 1928 & $\begin{array}{l}\text { All Goa's Chilun } \\
\text { Got Wings }\end{array}$ & 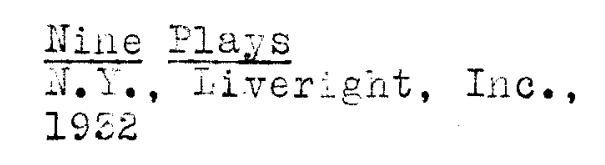 \\
\hline $1925-4-5$ & Ifreo lifilions & inne Plays \\
\hline 1924 & Desire Unoer the Elms & Mine Plays \\
\hline 1925 & The Grest Goü Brow & Vine $=1 \mathrm{kJS}$ \\
\hline $1925-26$ & Iazrus Jaughed & Wine Plays \\
\hline 1920 & Strange Interluae & Mine Elaxs \\
\hline 1928 & Dynano & $\begin{array}{l}\frac{\text { Djnamo }}{\text { M.Y. Horace Iiveright, }} \\
\text { I929 }\end{array}$ \\
\hline 1951 & $\begin{array}{l}\text { Nourning Becones } \\
\text { Electra }\end{array}$ & Mine Plays \\
\hline 1952 & An! Wilaerness & 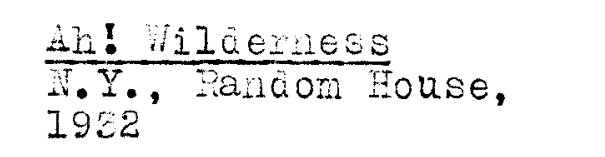 \\
\hline
\end{tabular}


1922-33 Days ithout End

Days Without End I. Y. , Random House, 1954

Criticel Bibliography

In the critical bibliogrephy onl those sources which have been quoted in the paper are included. All other critical bibliographic material has been listed in a supplenentary bibliography.

Clark, Barrett Earper

Eugene O'Neill: The Man ano His Plays

Ii. Y., Ropert T. Fitide o Co., 1929

Freud, sigmuna

The PSychology of Women

N.Y., W. W. Norton \& Co., 1926

Healy, Wu.; Bronner, Algusta; Bower, Anna liae

The Structure and leaning of Dotchoanclysis

F. T., kltred A. Klopf, ISEI

Krutcin, Joseph $100 \mathrm{~d}$

Introauction to Nine Playe By Eusene O'Neill

i. Y., inverignt, Inc., 1982

Luccock, Halford $\mathrm{E}$.

Contemporar anericen Iiterature and geligion

N.Y., Willet, CIsikE Co., 1924

Iturray, $\mathrm{Z}$, ana Young, J. C.

"liodern Licrriage"

Forum, po. 22-26, January, 1929

Quinn, Artinur Hobson

A History of the Anericen yrama from the Civil War

to the Present Jay, vol. I

1.Y., Harper \& Bros., 1927

Skinier, Kichara Dana

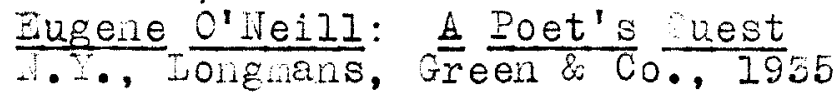

Trilling, Iionel

"Eugene O'iveill"

The Hew Republic, sept. 25,1926

Zabel, Morton Dawinen

Iiterary Opinion In America

T.Y., Harper \& Bros., 1957

"Eugene O'le II" D.

Francis revguson 
Supplenentary Bibilography

(Psychoanaly sis ana tarital Reletions)

Areuâ, sigrauà

New Introcuctory Lectures on asychosialysis

H.Y., .... Norton \& Co., 193

Groves, Ernest B.

Tisriage

i..., Fenry IoIt \& Co., 1933

Groves, Errest anc Ogburn, wh. D.

Gmerican arriage ana Bamilj geletions

T.Y., Eenry olt \&o., $\frac{1928}{\text { Cog }}$

Rosanofi, Aaron J.

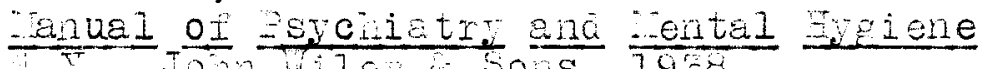

…, Jonin Wile es Sons, 1980

naller, willarò

ine ola Love ara the New

i. . Forace iveright, 1900

(Iiegarines anc Eeriodicale)

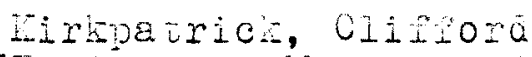

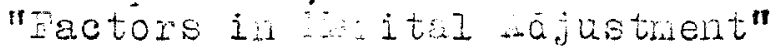

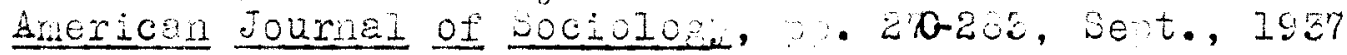

Lenisoni, Eunwe

"Eevico: nisiagen

Nation, $0.276-67$, Aril z, ISEL

"inline, ninc?

"What "ice Inficeitu?"

gorun, $\quad 87-70$, andist, 1927

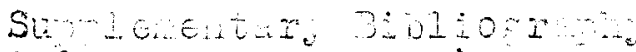

(o'Nein Criticisn)

Dickisoon, bones.

Iswigits of tie rew herican ineater

T. . Tecri Ian Co., 1925

Uicinison, Hons E.

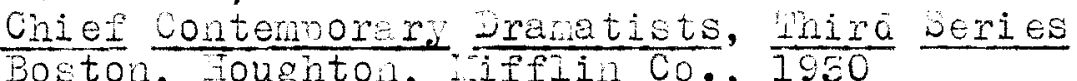

camilton, Clevton

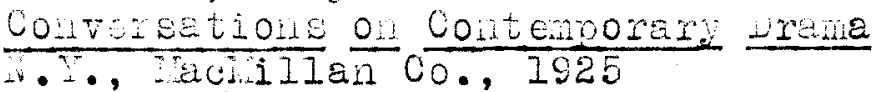


Yoses, Montrose J.

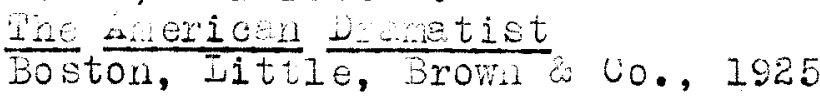

Sergesat, wizabeth shioman

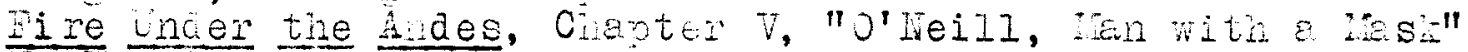
T. Y., RIIred A. Yilort, 192\%

(Periocicals and Fegazines):

CIaris, jarrett 1 .

"seschi lus ana orieili"

English Jourisi, $0.090-116$, November, 1922

Corbin, Jonis

"Orejil Backs anci Pilis"

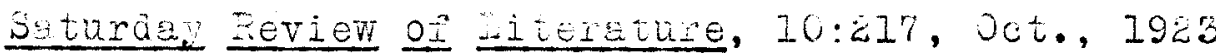

Tal buri, Weresa

"Orlil, ail imoreesion"

Saturac. Review of Diterture, I5:I0, 10v. 21, 1956

Trutch, Joseph Wooà

"Eeviev o? Gret Goa Bromn"

Hation, 122:164-1065, 1eb. 10, 1926

Ievisoni, Lünig

"bl1 Goc's Chiliun"

Netion, 118:664, Jan. 4, 1924

Nathail, veone Jean

"Review oz strange Interiude"

snerioar zerour, 11:400-500, sugust, 1927

Quin, Athur Fodon

"Significance op Hecent d eirican Drame"

Saribler's, 72: 97-148, July, 1922

Young, steriz

"Poet's Pilerinege"

New Eepublic, 84:2I0, 00t.2, ISe 